\title{
Exchange Rate Regimes, Devaluations and Growth Collapses
}

\author{
Michael Bleaney ${ }^{1}$, Sweta Saxena ${ }^{2}$ and Lin Yin ${ }^{3}$ \\ ${ }^{1}$ School of Economics, University of Nottingham, U.K. \\ ${ }^{2}$ Macroeconomic Policy and Financing for Development Division, United \\ Nations ESCAP, Bangkok, Thailand \\ ${ }^{3}$ Economic Research Department, China Railway Party School, P.R. China
}

\begin{abstract}
The loss of output in major recessions tends to be permanent. Using IMF de facto exchange rate regime classifications over the period 1980 to 2012 for up to 193 countries, it is shown that growth collapses are more frequent under less flexible exchange rate regimes, and particularly hard pegs. Amongst intermediate regimes, those with recent devaluations are less likely to experience a growth collapse, which confirms the role of exchange rate adjustment in reducing the output effects of a negative shock. Our findings are robust to the marked shift in the pattern of growth collapses after the global financial crisis.
\end{abstract}

Keywords: exchange rate regimes, devaluations, growth collapses, global financial crisis JEL No.: $\quad$ F31

Disclaimer: the views expressed in this paper are those of the authors and should not necessarily be considered as reflecting the views or carrying the endorsement of the United Nations.

${ }^{1}$ Corresponding author: Professor M F Bleaney, School of Economics, University of Nottingham, Nottingham NG7 2RD, UK. e-mail: michael.bleaney@nottingham.ac.uk. Tel. +44 115951 5464. Fax +44 1159514159. 


\section{INTRODUCTION}

Major recessions cause permanent losses of output. Although growth returns to its prerecession trend, output does not rebound back to the level that it would have reached had it continued to follow its previous trend; instead it tends to remain below it (Cerra and Saxena, 2008; Cerra et al., 2013). This raises some major issues for macroeconomic policy, such as the proper identification of the output gap after a big recession. Another implication is that, however well designed macroeconomic policy is in a general sense, it is particularly important not to make recessions worse, and if possible to make them milder.

Friedman (1953) argued that exchange rate flexibility could compensate for internal price rigidity in the face of external shocks, and that less flexible exchange rate regimes make output more vulnerable to shocks, because it is harder to compensate for the output effects of shocks by adjusting the real exchange rate. Broda (2004) and Edwards and Levy-Yeyati (2005) offer some evidence in support of this hypothesis, specifically for terms-of-trade shocks. If this hypothesis is correct, there is a danger that major recessions might occur under less flexible exchange rates that might have been avoided, or been significantly milder, with greater exchange rate flexibility. More recently, the experience of currency crises has drawn attention to the balance sheet effects of substantial real exchange rate depreciations where governments and firms have a large burden of debt denominated in foreign currency. In these circumstances, depreciations may lead to a collapse of investment because foreign lenders perceive a significantly increased risk of default, and the negative impact of this on output may outweigh the positive expenditure-switching effects (Céspedes et al., 2004; Cook, 2004). It is possible that this effect is highly non-linear, and is only significant for large depreciations $;^{1}$ and if so, it is also not clear that crises are associated with any particular

\footnotetext{
${ }^{1}$ It may also be asymmetric between appreciations and depreciations.
} 
exchange rate regime. Towbin and Weber (2013) find some evidence that high foreign debt reduces or eliminates entirely the shock-absorbing properties of floating exchange rates.

Thus the relationship between big recessions and the exchange rate regime remains an open question. In this paper we find significant evidence that growth collapses, in a sense to be defined, occur more frequently under less flexible exchange rate regimes, and particularly under hard pegs, than under more flexible ones, even allowing for the substantial shift in the cross-country pattern of these episodes after the global financial crisis.

The rest of the paper is structured as follows. Previous research is reviewed in Section Two. Data sources are explained and the empirical model is presented in Section Three. Section Four contains some preliminary data analysis. Empirical results appear in Section Five, and Section Six concludes.

\section{LITERATURE REVIEW}

Cerra and Saxena (2008) show that negative political and financial shocks often lead to a permanent loss of output relative to the pre-crisis trend. Cerra et al. (2013) undertake a detailed analysis of recoveries from episodes of negative growth, and find that the pace of growth in the first two years of the recovery is significantly slower than in other expansion years. They also find that more expansionary monetary and fiscal policies are associated with faster recoveries, and they present some evidence that recovery is stimulated by real exchange rate depreciation and that recovery is faster under floating exchange rates. These results motivate our interest in the correlation between the exchange rate regime and an economy's susceptibility to a major recession.

Some previous work has examined the relationship between the exchange rate regime and the output effect of shocks. Broda (2004) finds evidence that terms-of-trade shocks have 
bigger output effects under less flexible exchange rate regimes in a sample of 75 developing countries over the period 1973-96. Edwards and Levy-Yeyati (2005) obtain similar results for terms-of-trade shocks in a somewhat larger sample of 100 countries, and claim that output is more sensitive to negative than to positive shocks.

Lane and Milesi-Ferretti (2011) examine the output effects of the global financial crisis, which (as we shall see below) dramatically changed the cross-country incidence of growth collapses. They model GDP growth in the two-year period 2008-09 for a large sample of countries, including dummy variables for a hard peg and an intermediate exchange rate regime along with a variety of other variables. These exchange rate regime dummies emerge with negative coefficients (relative to the omitted category of a float), implying a deeper recession in less flexible regimes, but the evidence is no more than suggestive, because these variables never reach the five per cent level of significance. The significant variables in this regression are per capita GDP, the 2007 current account balance and the growth in private credit between 2004 and 2007. The 2008-09 recession was particularly bad in richer countries, and in those with fast credit growth and current account deficits. Calderón and Fuentes (2014) analyse the business cycle of 71 industrial and middle-income countries. They find that in middle-income countries recessions are generally deeper, steeper and costlier, but that the global financial crisis changed the pattern only in the industrial countries, where the recession was unusually deep and the recovery unusually slow.

Hausmann et al. (2005) were the first to focus attention on the turning points in growth rather than mean growth rates, in a study of growth accelerations. ${ }^{2}$ The focus of this research is shifts in trend growth rates rather than big recessions, and this line of investigation has subsequently been pursued using Markov switching models by Jerzmanowski (2006), Kar

\footnotetext{
${ }^{2}$ Rodrik (1999) was probably the first to use the term "growth collapse", but his empirical analysis does not focus on extreme events (his dependent variable is the change in the growth rate between 1960-75 and 197589).
} 
et al. (2013) and Kerekes (2012). Hausmann et al. (2006) study growth collapses, which they define as episodes of negative growth in GDP per person of working age, but they do not investigate the role of the exchange rate regime.

Ghosh et al. (2015) consider the vulnerabilities of different exchange rate regimes in 51 middle-income countries over a number of dimensions, including lending booms, various types of crises and growth collapses. They find that, although pegs (either hard or soft) are not especially susceptible to banking crises, currency crises or sovereign debt crises, they are significantly more prone to growth collapses compared with independent floats. They define a growth collapse as the bottom fifth percentile of the distribution of the growth rate of real GDP in year $t$ minus its average in the three years $t-3$ to $t-1$, which turns out to mean a fall of at least 7.5 percentage points. Such a large fall almost certainly means that growth is negative, but there may be many episodes of negative growth in the sense of Hausmann et al. (2006) that do not qualify as a growth collapse according to this definition. A limitation of Ghosh et al.'s work is that, because their sample consists of middle-income countries only, it contains only a very limited number of hard pegs (nine); moreover they also find, somewhat surprisingly, that soft pegs to a single currency and basket pegs are even more susceptible to growth collapses than hard pegs. Thus there is no clear pattern of susceptibility to growth collapses decreasing with the flexibility of the exchange rate regime in their results.

Towbin and Weber (2013) estimate a panel vector autoregression in which they allow the response of output and investment to external shocks to vary with the exchange rate regime and also with the ratio of foreign-currency debt to GDP (to capture balance sheet effects) and with the share of primary products in imports (as a proxy for exchange-rate passthrough). On average output responds more to shocks under pegging, but this effect largely 
disappears or can even be reversed when foreign-currency debt is high or exchange-rate passthrough is limited. ${ }^{3}$

The present paper contributes to the literature in several ways. First, it investigates the exchange rate regime effect for a global sample of growth collapses, controlling for differences in country types and for the special circumstances surrounding the global financial crisis. Second, it allows for major crisis events, such as banking and currency crises, and considers whether the exchange rate regime effect is markedly different in the presence of such crises compared with "normal" periods. Third, it shows that pegged regimes with recent devaluations have a lower probability of a growth collapse than pegged regimes without recent devaluations, which confirms the role of exchange rate adjustment in reducing the output effects of negative shocks. Fourth, since there is no agreed definition of a growth collapse, the paper uses several different measures as a test of the robustness of the results. The conclusion is that there is a marked negative correlation between the probability of a growth collapse and the flexibility of the exchange rate regime.

\section{DATA AND THE EMPIRICAL MODEL}

Large shocks associated with a sharp reduction in the growth rate of output lead to permanent output losses. We term such an episode a "growth collapse". Our purpose is to test whether the probability of a growth collapse in country $j$ in year $t$ is greater, other things equal, if the exchange rate regime is less flexible. With a flexible exchange rate, a negative shock is likely to trigger a real exchange rate depreciation that switches expenditure from foreign to home goods, thus mitigating the negative impact on output, although there may be offsetting

\footnotetext{
${ }^{3}$ The relevance of pass-through is that it is necessary for the relative price adjustments that give rise to expenditure-switching.
} 
balance-sheet effects. With a fixed exchange rate, such a real depreciation tends to be prevented by downward price rigidity. The nature of the shock is not particularly important, and we do not attempt to model it, except that we allow for a different exchange rate effect in the wake of major crisis events. Empirically, we model the probability of a growth collapse as a function of a series of measures of crisis and some other controls such as dummies for country types. At a later stage we allow for some interaction of the exchange rate regime with per capita income and trade openness.

The exchange rate regime is captured by a set of one-zero dummy variables, the omitted category being the most flexible regime. The hypothesis is that, since the most flexible regime is the omitted category, the exchange rate dummies have positive coefficients that increase with the fixity of the regime, implying that growth collapses are more likely with a less flexible regime. Various other controls, including time dummies, are included in the model, reflecting other factors that may affect the probability of a growth collapse. Formally, the model may be written:

$\operatorname{Pr}\left(\right.$ collapse $\left._{j t}\right)=\alpha_{t}+\beta R E G I M E_{j t-1}+\gamma$ CRISIS $_{j t-1}+$ CONTROLS $_{j t}+\varepsilon_{j t}$

where $\operatorname{Pr}\left(\right.$ collapse $\left._{j t}\right)$ is the probability of a growth collapse (in a sense yet to be defined) in country $j$ in year $t, R E G I M E$ is a set of exchange rate regime dummies, CRISIS is a dummy variable that equals one in crisis years, as defined below, and zero otherwise, CONTROLS is a set of control variables and $\varepsilon$ is a random error. This is a linear probability model with time dummies, but we show in the Appendix that we get similar results with a probit model.

The exchange rate regime data are from Ghosh et al. (2015), which is essentially the IMF de facto classification. We use both the aggregated classification (hard pegs, intermediate regimes and independent floats) and the fine classification that separates hard pegs into no legal tender and currency boards, and splits intermediate regimes into pegs to a 
single currency, other pegs or bands and managed floats. The IMF de facto classification is based on IMF country desks' assessment of the exchange rate regime according to certain criteria, so one might describe it as statistically based but informed by judgement. In our view this is probably the best approach. Alternatives are the classification of Reinhart and Rogoff (2004), which has been updated but has the flaw that it fails to identify some types of independent float (Bleaney et al., 2017, p. 377), or that of Bleaney and Tian (2017), which is only binary (peg or band versus managed or independent float). ${ }^{4} \mathrm{We}$ can, however, use the classification of Bleaney and Tian (2017) to identify country-years in which intermediate regimes have experienced a significant parity change (this classification uses a regression of the kind previously used to identify the components of a basket peg to test whether the peg has been subject to a parity change).

Growth collapses do not have a universally accepted definition. Here they are defined as growth in the current year at least five percentage points below the average of the previous three years, where growth is the percentage rate of change of GDP in constant local currency, as given in the World Bank's World Development Indicators database. We also consider a definition that allows for the fact that some countries have intrinsically greater volatility. Some people may consider that a negative growth rate is a necessary characteristic of a growth collapse, so we investigate whether this makes a difference to our results.

We form a panel dataset for currency crises by constructing an exchange market pressure index (EMPI) for each country. The EMPI is defined as the percentage depreciation in the exchange rate plus the percentage loss in foreign exchange reserves. This formulation makes indices comparable across countries. ${ }^{5} \mathrm{~A}$ dummy variable for a currency crisis is

\footnotetext{
${ }^{4}$ Some results with these alternative classifications appear in Table A3 of the online Appendix.

${ }^{5}$ The crisis literature often normalizes reserves and exchange rate movements by their within-country standard deviations, but then the magnitudes of the EMPI are comparable only within countries. Some authors
} 
formed for a specific year and country if the EMPI is in the upper five percent of all observations across the panel. An alternative currency measure that we use is available from Laeven and Valencia (2013). The main difference is that their measure takes account only of exchange rate depreciation and not of reserve losses. ${ }^{6}$

The dates for banking and debt crises are taken from Laeven and Valencia (2013). They define a banking crisis as systemic if one of two conditions is met: either (i) there are significant signs of financial distress in the banking system (as indicated by significant bank runs, losses in the banking system, and/or bank liquidations); or (ii) there are significant banking policy intervention measures in response to losses in the banking system. Debt crises are episodes of sovereign debt default or restructuring crises, the information for which is compiled from several sources.

For most of the regressions, we do not differentiate between types of crisis but simply use the variable Crisis ${ }_{i, t}$ to denote that country $i$ experienced one of these crises in year $t$. In a few cases, we split this variable to indicate whether it was a currency, banking or debt crisis.

\section{PRELIMINARY DATA ANALYSIS}

Table 1 shows the frequency of growth collapses by exchange rate regime, both for the whole sample and for separate country groups. The general pattern for all the sub-samples is that the frequency of growth collapses is greater, the less flexible the exchange rate regime.

Figure 1 shows the time pattern of growth collapses, defined as growth in the current year at least five percentage points below the average of the previous three years, from 1983

\footnotetext{
also take account of interest rates as a defence against speculative attacks; we omit interest rates because of the scarcity of data.

${ }^{6}$ They code a currency crisis if the exchange rate depreciates by more than $30 \%$ against the US dollar and this is at least $10 \%$ more than the year before, so the depreciation has to be both large and accelerating.
} 
to $2011 .^{7}$ The 2009 peak, when growth collapses represented $44.6 \%$ of the sample, dwarfs any other (maximum $17.6 \%$ in 1991). To allow for the growth collapses associated with the global financial crisis to be somewhat different (for example sub-Saharan Africa was very little affected), we initially analyse the period 1983-2005 and 2006-2012 separately.

Table 1. Growth collapses and exchange rate regimes 1980-2012

\begin{tabular}{|c|c|c|c|}
\hline Sample & $\begin{array}{c}\text { Exchange rate } \\
\text { regime (t-1) }\end{array}$ & Growth collapse & No growth collapse \\
\hline \multirow{3}{*}{ All countries } & Float & $33(6.0 \%)$ & $514(94.0 \%)$ \\
\cline { 2 - 4 } & Intermediate & $338(10.5 \%)$ & $2879(89.5 \%)$ \\
\cline { 2 - 4 } & Hard Peg & $145(14.5 \%)$ & $852(85.7 \%)$ \\
\hline \multirow{3}{*}{$\begin{array}{c}\text { Advanced } \\
\text { economies }\end{array}$} & Float & $7(2.9 \%)$ & $231(97.1 \%)$ \\
\cline { 2 - 4 } & Intermediate & $27(5.6 \%)$ & $458(94.4 \%)$ \\
\hline \multirow{3}{*}{\begin{tabular}{c} 
Emerging markets \\
\cline { 2 - 4 }
\end{tabular}} & Hard Peg & $24(11.1 \%)$ & $193(88.9 \%)$ \\
\cline { 2 - 4 } & Intermediate & $147(10.4 \%)$ & $155(94.5 \%)$ \\
\cline { 2 - 4 } & Hard Peg & $15(17.4 \%)$ & $71(82.6 \%)$ \\
\hline \multirow{3}{*}{\begin{tabular}{c} 
Sub-Saharan Africa \\
\cline { 2 - 4 }
\end{tabular}} & Float & $15(12.7 \%)$ & $103(87.3 \%)$ \\
\cline { 2 - 4 } & Intermediate & $81(12.3 \%)$ & $579(87.7 \%)$ \\
\hline & Hard Peg & $65(16.0 \%)$ & $342(84.0 \%)$ \\
\hline \multirow{2}{*}{$\begin{array}{c}\text { Other developing } \\
\text { countries }\end{array}$} & Float & $4(8.7 \%)$ & $42(92.3 \%)$ \\
\cline { 2 - 4 } & Intermediate & $128(11.8 \%)$ & $958(88.2 \%)$ \\
\cline { 2 - 4 } & Hard Peg & $43(14.0 \%)$ & $265(86.0 \%)$ \\
\hline
\end{tabular}

Notes. A growth collapse is defined as a growth rate at least five percentage points below the average of the previous three years.

\footnotetext{
${ }^{7}$ In the sample growth collapses represent just over $10 \%$ of the observations, which is about twice as many as GOQ's definition, but a $5 \%$ drop seems sharp enough to qualify.
} 
Figure 1. Percentage of growth collapses by year

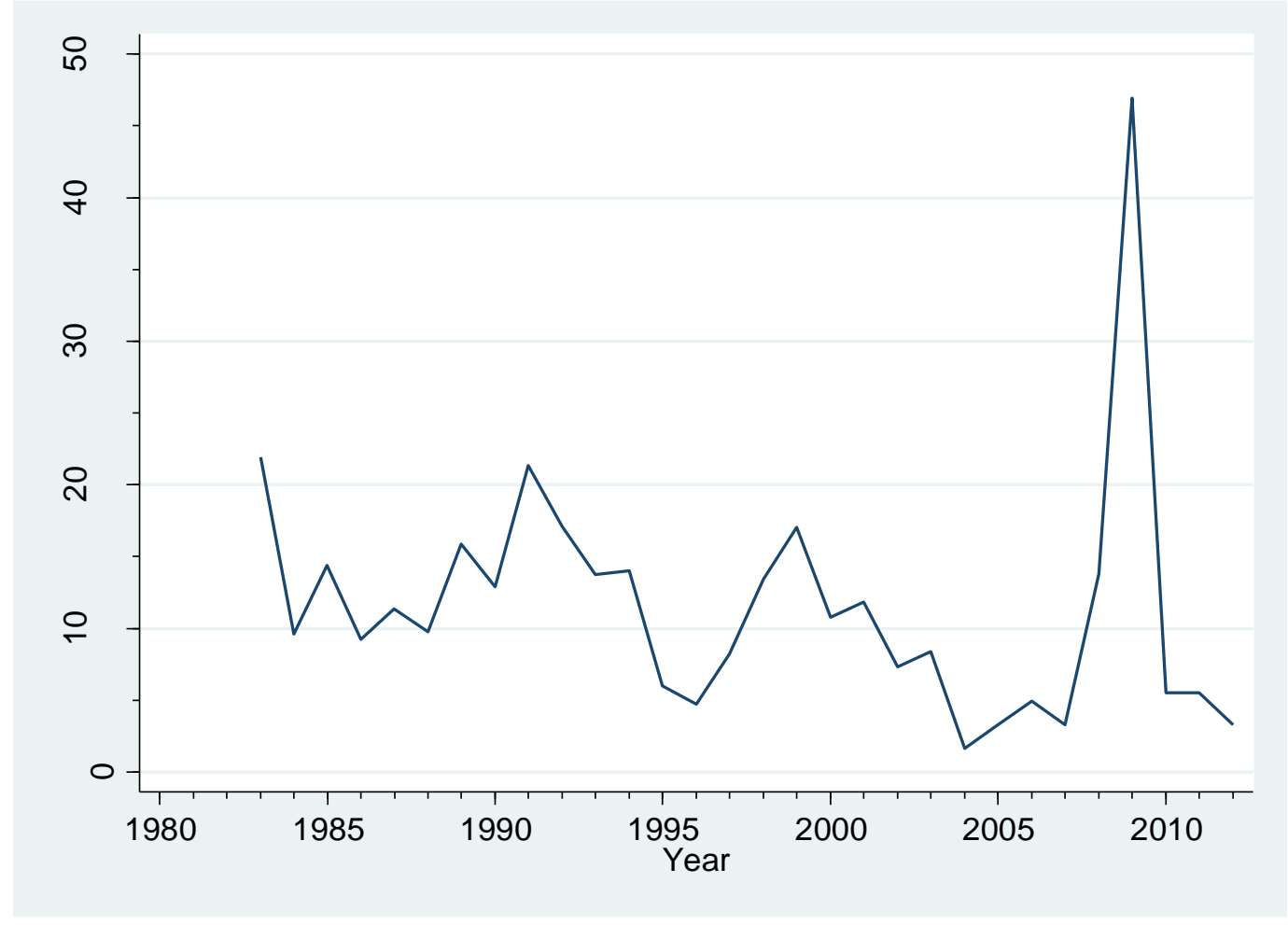

Note. A growth collapse is defined as a growth rate at least five percentage points below the average of the previous three years. 


\section{EMPIRICAL RESULTS}

\section{Susceptibility to a growth collapse increases with the rigidity of the exchange rate regime, and more so for advanced economies after the global financial crisis}

Growth collapses are potentially important because of their long-term output effects, as Cerra and Saxena (2005) and Cerra et al. (2013) argue. Table A1 in the online Appendix illustrates their point using our data. We begin our analysis of growth collapses with a simple model in which the probability of a growth collapse is a function of the exchange rate regime and a crisis measure, without any interaction between them. The model includes time fixed effects, and standard errors are clustered by country. We assume that different types of countries may have different degrees of susceptibility to a growth collapse, by including dummy variables for (a) the advanced countries, (b) emerging markets and (c) sub-Saharan Africa, the omitted category being developing countries outside sub-Saharan Africa. ${ }^{8}$ We also allow for the cross-country incidence of growth collapses to have changed during the global financial crisis by allowing theses dummy variables to have different coefficients from 2006 onwards. The crisis measure is a banking, debt or currency crisis in the previous year. This model reveals a systematic association between the (in)flexibility of the exchange rate regime and the economy's susceptibility to growth collapses. We test the robustness of the model in a variety of ways.

Our basic results for the probability of a growth collapse (defined as a GDP growth rate at least five percentage points below the average of the previous three years) are presented in Table 2. The first two columns use data from before the global financial crisis (1980-2005) and the last two use more recent data (2006-12). The reason for this split is immediately apparent when we compare the coefficients, which are often quite different in

\footnotetext{
${ }^{8}$ The countries in each group are listed in the online Appendix.
} 
the two periods. For example the advanced country dummy has a highly significant negative coefficient up to 2005 , but a positive one thereafter, whereas the dummies for emerging markets and sub-Saharan Africa have significant positive coefficients in the earlier period. In other words, the norm before the global financial crisis was that growth collapses were more common in poorer countries (supported by Cerra and Saxena, 2005), but during the crisis if anything they were more common in richer countries (see Cerra and Saxena, 2017).

The first column of Table 2 uses a coarse exchange rate regime classification: hard pegs, independent floats (the omitted category) and intermediate regimes (the rest). Controlling for crises and the type of country, up to 2005 the probability of a growth collapse under a hard peg was 5.7 percentage points greater than under an independent float, and the coefficient is significant at the five per cent level. For an intermediate regime the difference compared to a float, although still positive, is much smaller (1.2 percentage points) and not statistically significant. In other words, the less flexible the exchange rate regime, the greater the risk of a growth collapse.

The second column of Table 2 uses the fine classification of exchange rate regimes, also for the period up to 2005 , but otherwise the specification is identical to that of the first column. Hard pegs are separated into two categories: those countries that are members of a currency union or have adopted the currency of another country (no separate legal tender) and currency boards. Intermediate regimes are separated into three categories: horizontal singlecurrency pegs, managed floats, and lastly other pegs and bands, a grouping which combines the thinly populated categories of horizontal bands, basket pegs, crawling pegs, and crawling bands. ${ }^{9}$ Currency boards $(8.2 \%)$ are estimated to have a larger impact on the probability of a growth collapse than currency unions (5.3\%), but both these coefficients are higher than for soft pegs to a single currency (2.0\%) and other pegs and bands (2.2\%). Managed floats

\footnotetext{
${ }^{9} \mathrm{~A}$ band allows a greater range of variation about the central rate than a peg.
} 
actually have a small negative coefficient. The non-regime coefficients in column (2) of Table 2 are very similar to those in column (1).

The third and fourth columns of Table 2 reproduce the specifications of columns (1) and (2), but applied to data from 2006 to 2012. In both regressions the estimated regime effects are rather larger than those in Column (1), as is also the estimated crisis effect. For example in the coarse classification (Column (3)), the estimated hard-peg effect is $11.4 \%$ and the estimated intermediate-regime effect is $8.9 \%$, in both cases significant at the $1 \%$ level. In the fine classification (Column (4)), the regime coefficients are all considerably higher than in Column (2), except in the case of currency unions, and four out of five are significant at the $1 \%$ level. In both Column (3) and Column (4), the crisis coefficient is higher than in the earlier period. Taken as a whole these results are highly consistent with the theory that flexibility of the exchange rate regime reduces a country's susceptibility to a growth collapse, and that the greater the degree of flexibility, the lower is this susceptibility.

It is also of interest to estimate the model separately for the different country groups: advanced economies, emerging markets, sub-Saharan Africa and other developing countries. This is done in Table 3. As was to be expected from our previous results, the coefficient of this dummy variable varies considerably by country type. Indeed there is a striking pattern: both the regime effects and the crisis effect are driven by advanced economies and emerging markets, rather than developing countries. 
Table 2. A probability analysis of exchange rate regimes and growth collapses

\begin{tabular}{|c|c|c|c|c|}
\hline & \multicolumn{2}{|c|}{ 1983-2005 } & \multicolumn{2}{|c|}{$2006-12$} \\
\hline & $(1)$ & (2) & (3) & (4) \\
\hline $\begin{array}{l}\text { Hard peg } \\
(\mathrm{t}-1)\end{array}$ & $\begin{array}{c}0.0572 * * \\
(1.98)\end{array}$ & & $\begin{array}{c}0.1138 * * * \\
(3.36)\end{array}$ & \\
\hline $\begin{array}{c}\text { No separate } \\
\text { legal tender }(\mathrm{t}-1)\end{array}$ & & $\begin{array}{c}0.0527 * \\
(1.63) \\
\end{array}$ & & $\begin{array}{c}0.1330^{* * * *} \\
(3.12)\end{array}$ \\
\hline $\begin{array}{c}\text { Currency board } \\
\text { (t-1) }\end{array}$ & & $\begin{array}{c}0.0817 * \\
(1.89) \\
\end{array}$ & & $\begin{array}{c}0.0814 * * \\
(2.07)\end{array}$ \\
\hline $\begin{array}{l}\text { Intermediate } \\
\text { regime }(\mathrm{t}-1)\end{array}$ & $\begin{array}{l}0.0116 \\
(0.62)\end{array}$ & & $\begin{array}{c}0.0891 * * * \\
(3.38)\end{array}$ & \\
\hline $\begin{array}{l}\text { Peg to single } \\
\text { currency } \\
(\mathrm{t}-1)\end{array}$ & & $\begin{array}{c}0.0199 \\
(0.85)\end{array}$ & & $\begin{array}{c}0.0955^{* * *} * \\
(3.10)\end{array}$ \\
\hline $\begin{array}{l}\text { Other peg/band } \\
(\mathrm{t}-1)\end{array}$ & & $\begin{array}{c}0.0216 \\
(1.01)\end{array}$ & & $\begin{array}{c}0.1166 * * * \\
(3.02)\end{array}$ \\
\hline $\begin{array}{c}\text { Managed float } \\
(\mathrm{t}-1)\end{array}$ & & $\begin{array}{r}-0.0074 \\
(-0.36)\end{array}$ & & $\begin{array}{c}0.0838 * * * \\
(2.99)\end{array}$ \\
\hline $\begin{array}{c}\text { Advanced } \\
\text { country dummy }\end{array}$ & $\begin{array}{c}-0.0360 * * \\
(-2.41)\end{array}$ & $\begin{array}{c}-0.0373 * * \\
(-2.37)\end{array}$ & $\begin{array}{l}0.0424 \\
(1.49)\end{array}$ & $\begin{array}{l}0.0487 \\
(1.64)\end{array}$ \\
\hline $\begin{array}{c}\text { Emerging } \\
\text { markets dummy }\end{array}$ & $\begin{array}{c}0.0268 * \\
(1.72)\end{array}$ & $\begin{array}{c}0.0271 * \\
(1.74)\end{array}$ & $\begin{array}{l}0.0045 \\
(0.17)\end{array}$ & $\begin{array}{c}0.0080 \\
(0.32)\end{array}$ \\
\hline SSA dummy & $\begin{array}{c}0.0598 * * * \\
(2.92)\end{array}$ & $\begin{array}{c}0.0625 * * * \\
(3.03)\end{array}$ & $\begin{array}{l}-0.0206 \\
(-0.88)\end{array}$ & $\begin{array}{l}-0.0302 \\
(-0.99)\end{array}$ \\
\hline Crisis $(\mathrm{t}-1)$ & $\begin{array}{c}0.0583 * * * \\
(2.61)\end{array}$ & $\begin{array}{l}0.0596 * * * \\
(2.67)\end{array}$ & $\begin{array}{c}0.0781 * * * \\
(2.63)\end{array}$ & $\begin{array}{c}0.2047 * * * \\
(2.66)\end{array}$ \\
\hline Year dummies? & Yes & Yes & Yes & Yes \\
\hline Sample size & 2854 & 2854 & 960 & 960 \\
\hline R-squared & 0.0501 & 0.0515 & 0.2131 & 0.2148 \\
\hline
\end{tabular}

Notes. The dependent variable is binary (growth collapse $=1$; no growth collapse=0), where a growth collapse is defined as a growth rate at least five percentage points below the average of the previous three years. The omitted regime category is an independent float, and the omitted country category is developing countries outside sub-Saharan Africa. The figures in parentheses are heteroscedasticity-robust $z$-statistics clustered by country. $*, * *, * * *$ : significantly different from zero at the 10,5 and $1 \%$ levels respectively. 
Table 3. A probability analysis of exchange rate regimes and growth collapses by country group

\begin{tabular}{|c|c|c|c|c|}
\hline & $\begin{array}{c}\text { Advanced } \\
\text { economies }\end{array}$ & $\begin{array}{c}\text { Emerging } \\
\text { markets }\end{array}$ & $\begin{array}{c}\text { Sub-Saharan } \\
\text { Africa }\end{array}$ & $\begin{array}{c}\text { Developing } \\
\text { economies } \\
\text { (except SSA) }\end{array}$ \\
\hline Hard peg & $0.1198^{* * *}$ & $0.1407 * * *$ & 0.0162 & $(4)$ \\
$(\mathrm{t}-1)$ & $(3.08)$ & $(4.24)$ & $(0.28)$ & 0.0002 \\
\hline Intermediate & $0.0528^{* * *}$ & $0.0357^{* *}$ & -0.0166 & -0.0144 \\
regime (t-1) & $(2.92)$ & $(2.05)$ & $(-0.31)$ & $(-0.35)$ \\
\hline Crisis (t-1) & $0.261 * *$ & $0.164^{* * *}$ & $0.0528^{*}$ & $-0.0785^{* *}$ \\
& $(2.30)$ & $(4.48)$ & $(1.75)$ & $(-3.10)$ \\
\hline Year dummies & Yes & Yes & Yes & Yes \\
\hline Sample size & 705 & 1213 & 1144 & 845 \\
\hline R-squared & 0.3064 & 0.2109 & 0.0612 & 0.1296 \\
\hline
\end{tabular}

Notes. See notes to Table 2. The dependent variable is binary (growth collapse=1; no growth collapse $=0$ ), where a growth collapse is defined as a growth rate at least five percentage points below the average of the previous three years. The data period is 1980-2012. 
In the remaining tables we stick to the coarse exchange rate regime classification, and add some control variables to the regression. The control variables are: consumer price inflation, the ratio of the current account balance to GDP, and the change in the logarithm of the terms of trade. In order to separate inflation effects at moderate levels from those at high levels, the inflation variable is split into two: "inflation1", which is truncated at a maximum of $25 \%$, and "inflation2", which is equal to the inflation rate minus $25 \%$, truncated at a minimum of zero (and which therefore has no effect unless inflation is above 25\%). Although the control variables are often insignificant, we retain them as insurance against omitted variable bias.

In Table 4 we explore what happens if we use the data for the whole period, but allow the coefficients of the dummies for country type to be different in the later period. The new control variables at the foot of the table are never significant. Amongst the regional dummies, only that for sub-Saharan Africa is significant. It is significantly positive by itself, but when interacted with the post-2005 dummy it is significantly negative and even larger in absolute value. This means that growth collapses were significantly more frequent in sub-Saharan Africa than elsewhere up to 2005, but not since. 
Table 4. The full sample with structural breaks and omitting years succeeding a growth collapse

\begin{tabular}{|c|c|c|c|c|}
\hline & (GDP growth & $\begin{array}{l}\text { Jrowth collap } \\
\text { r more below } \\
\text { three years) }\end{array}$ & ge of previous & $\begin{array}{c}\text { Omitting } \\
\text { observations } \\
\text { within four } \\
\text { years of a }\end{array}$ \\
\hline & (1) & $(2)$ & (3) & (4) \\
\hline $\begin{array}{l}\text { Hard peg } \\
(\mathrm{t}-1)\end{array}$ & $\begin{array}{c}0.0800 * * * \\
(3.24)\end{array}$ & $\begin{array}{c}0.0658 * * * \\
(3.26)\end{array}$ & $\begin{array}{c}0.0784 * * * \\
(4.00)\end{array}$ & $\begin{array}{c}0.0607 * * \\
(2.39)\end{array}$ \\
\hline $\begin{array}{c}\text { Intermediate } \\
\text { regime }(\mathrm{t}-1)\end{array}$ & $\begin{array}{l}0.0426 * * * \\
(2.63)\end{array}$ & $\begin{array}{c}0.0346 * * \\
(2.16)\end{array}$ & $\begin{array}{c}0.0330 * * \\
(2.09)\end{array}$ & $\begin{array}{l}0.0259 \\
(1.50)\end{array}$ \\
\hline $\begin{array}{c}\text { Advanced } \\
\text { country dummy }\end{array}$ & $\begin{array}{c}0.0126 \\
(0.72) \\
\end{array}$ & $\begin{array}{l}0.0001 \\
(0.01)\end{array}$ & $\begin{array}{c}-0.0104 \\
(-0.59) \\
\end{array}$ & $\begin{array}{c}0.0352 \\
(1.61)\end{array}$ \\
\hline $\begin{array}{c}\text { Emerging } \\
\text { markets dummy }\end{array}$ & $\begin{array}{l}0.0276 \\
(1.53) \\
\end{array}$ & $\begin{array}{l}0.0182 \\
(1.05) \\
\end{array}$ & $\begin{array}{l}0.0103 \\
(0.59) \\
\end{array}$ & $\begin{array}{c}0.0426 * * \\
(2.32)\end{array}$ \\
\hline SSA dummy & $\begin{array}{c}0.0753^{* * * *} \\
(3.29)\end{array}$ & $\begin{array}{c}0.0699 * * * \\
(3.23)\end{array}$ & $\begin{array}{c}0.0574 * * * \\
(2.69)\end{array}$ & $\begin{array}{c}0.0575^{* *} \\
(2.57)\end{array}$ \\
\hline $\begin{array}{l}\text { Dummy 2006- } \\
12 * \text { Advanced }\end{array}$ & $\begin{array}{l}0.0103 \\
(0.34)\end{array}$ & $\begin{array}{l}0.0097 \\
(0.35)\end{array}$ & $\begin{array}{l}0.0224 \\
(0.87)\end{array}$ & $\begin{array}{l}-0.0067 \\
(-0.16)\end{array}$ \\
\hline $\begin{array}{c}\text { Dummy 2006- } \\
12 * \mathrm{EM}\end{array}$ & $\begin{array}{c}-0.0216 \\
(-0.78) \\
\end{array}$ & $\begin{array}{l}-0.0123 \\
(-0.47)\end{array}$ & $\begin{array}{c}-0.0046 \\
(-0.19)\end{array}$ & $\begin{array}{c}-0.0258 \\
(-0.78)\end{array}$ \\
\hline $\begin{array}{c}\text { Dummy 2006- } \\
12 * \text { SSA }\end{array}$ & $\begin{array}{c}-0.0984 * * * \\
(-2.96) \\
\end{array}$ & $\begin{array}{c}-0.0908 * * * \\
(-2.92)\end{array}$ & $\begin{array}{c}-0.0839 * * * \\
(-2.86)\end{array}$ & $\begin{array}{c}-0.0956 * * * \\
(-2.72) \\
\end{array}$ \\
\hline Crisis (t-1) & $\begin{array}{c}0.0816^{* * * *} \\
(3.16)\end{array}$ & & & $\begin{array}{l}0.0397 \\
(0.94) \\
\end{array}$ \\
\hline LV Crisis (t-1) & & $\begin{array}{c}0.0834 * * * \\
(3.20)\end{array}$ & & \\
\hline Inflation1 & $\begin{array}{c}0.00110 \\
(0.87)\end{array}$ & $\begin{array}{c}0.00112 \\
(0.98)\end{array}$ & $\begin{array}{c}0.00181 \\
(1.65)\end{array}$ & $\begin{array}{c}0.00014 \\
(0.10)\end{array}$ \\
\hline $\begin{array}{c}\text { Inflation } 2 \\
\text { divided by } 10^{6}\end{array}$ & $\begin{array}{c}-1.52 \\
(-0.34)\end{array}$ & $\begin{array}{c}6.66 \\
(1.24)\end{array}$ & $\begin{array}{c}5.89 \\
(1.16)\end{array}$ & $\begin{array}{c}1590 * * * \\
(8.22)\end{array}$ \\
\hline $\begin{array}{l}\text { Current Acc. } \\
\text { /GDP }\end{array}$ & $\begin{array}{l}0.0876 \\
(1.06)\end{array}$ & $\begin{array}{l}0.0608 \\
(0.77)\end{array}$ & $\begin{array}{l}0.0476 \\
(0.66)\end{array}$ & $\begin{array}{l}-0.0403 \\
(-0.51)\end{array}$ \\
\hline Dln TOT & $\begin{array}{c}-0.0037 \\
(-0.07)\end{array}$ & $\begin{array}{c}0.0160 \\
(0.30)\end{array}$ & $\begin{array}{l}0.0325 \\
(0.61)\end{array}$ & $\begin{array}{c}0.0812 \\
(1.23)\end{array}$ \\
\hline Year dummies & Yes & Yes & Yes & Yes \\
\hline Sample size & 2924 & 3214 & 3430 & 1771 \\
\hline R-squared & 0.1148 & 0.1237 & 0.1206 & 0.1393 \\
\hline
\end{tabular}

Notes. See notes to Table 2. The sample is 1980 to 2012. LV crisis: Laeven-Valencia (2013) measure of currency, banking or debt crisis. Inflation $1=$ consumer price inflation (maximum $25 \%$ ). Inflation 2 = consumer price inflation minus $25 \%$ (minimum zero). TOT: terms of trade. 
In Column (1) of Table 4 the estimated hard-peg effect of $+8.0 \%$ is nearly twice as large as the estimated intermediate-regime effect of $+4.3 \%$, and both are significant at $1 \%$. The coefficient of the crisis dummy is also highly significant. We shall use this regression as the benchmark for the rest of the paper. In Column (2) we replace our currency crisis measure with the Laeven-Valencia measure; the results are similar except that all the significant coefficients are a little bit less significant. If crises are associated with a particular exchange rate regime, we could be accused of biasing our results by including a crisis dummy. Accordingly in Column (3) we omit it; the results remain robust. This is not surprising because neither of the two crises measures are associated with any particular exchange rate regime; the probability of a crisis is very similar for hard pegs, intermediate regimes and floats, and the same is true of the different types of crisis (banking, debt or currency crisis).

So far we have assumed that the probability of a growth collapse is independent of whether one has recently occurred. This seems implausible for two reasons. One is that if the growth rate falls sharply in each of the two years $T$ and $T+1$, there is a strong possibility that year $T+1$ will qualify as a growth collapse if year $T$ has done so. This could happen if there is a prolonged deceleration of output growth. The other is that, once a growth collapse comes to an end, the lagged three-year average growth rate will be low, which makes a further growth collapse unlikely. So, after a growth collapse ending in year T, a further collapse in years $T+1$ to $T+3$ is improbable. To address this issue, in Column (4) of Table 4 we re-estimate the regression of Column (1) with exactly the same specification but omitting years where there was a growth collapse in any of the previous four years. This loses over 1200 out of nearly 3000 observations, which inevitably increases the standard errors. The hard peg coefficient of $6.07 \%$ in Column (4) is smaller than in Column (1), but still significant at the 5\% level; the intermediate regime coefficient remains positive but falls to an insignificant $2.6 \%$. 
The terms-of-trade effect in Table 4 is always insignificant, and indeed the coefficient is only negative as expected in Column (1). It might be argued that the terms-of-trade effect might be particularly an issue for primary commodity exporters, whose export prices are volatile. ${ }^{10}$ In Table A4 of the online Appendix, we report the results of re-estimating Table 4, allowing for commodity-exporting countries to have a different terms-of-trade coefficient. The terms-of-trade coefficient does tend to be more negative (or less positive) for commodity-exporting countries than for the rest of the sample, but it is never close to statistical significance.

So far we have not differentiated between different types of crisis. The results are shown in Table 5. The one type of crisis that consistently emerges as positively correlated with growth collapses is a banking crisis, which has a positive coefficient that is significant at $1 \%$ in all three columns of Table 5. Debt crises are never significant, although they have a positive coefficient in all three columns. What differentiates the columns of Table 5 from one another is the measure of currency crises. Column (1) uses our preferred measure, with a 5\% threshold. Its coefficient is positive, but with a t-statistic of only 1.26. Column (2) uses LV's currency crisis measure, which takes account only of exchange rate depreciation and not reserve losses. This measure even emerges with a negative coefficient, although it is small and insignificant. Finally, in Column (3), we relax the threshold for coding a currency crisis so that currency crises represent $10 \%$ of the observations, and this raises the coefficient to a level where it is significant at the $5 \%$ level.

\footnotetext{
${ }^{10}$ We are grateful to an anonymous referee for this point.
} 
Table 5. Different types of crises

\begin{tabular}{|c|c|c|c|}
\hline & \multicolumn{3}{|c|}{$\begin{array}{c}\text { Growth collapse } \\
\text { (GDP growth } 5 \% \text { or more below average of previous three years) }\end{array}$} \\
\hline & (1) & (2) & (3) \\
\hline $\begin{array}{c}\text { Hard peg } \\
(\mathrm{t}-1)\end{array}$ & $\begin{array}{c}0.0811 * * * \\
(3.29)\end{array}$ & $\begin{array}{c}0.0646 * * * \\
(3.20)\end{array}$ & $\begin{array}{l}0.0805 * * * \\
(3.28)\end{array}$ \\
\hline $\begin{array}{c}\text { Intermediate regime } \\
(\mathrm{t}-1)\end{array}$ & $\begin{array}{c}0.0429 * * * \\
(2.67)\end{array}$ & $\begin{array}{c}0.0339 * * \\
(2.11)\end{array}$ & $\begin{array}{c}0.0437 * * * \\
(2.74)\end{array}$ \\
\hline $\begin{array}{l}\text { Advanced country } \\
\text { dummy }\end{array}$ & $\begin{array}{l}0.0123 \\
(0.68)\end{array}$ & $\begin{array}{c}-0.0136 \\
(-0.08)\end{array}$ & $\begin{array}{l}0.0143 \\
(0.80)\end{array}$ \\
\hline $\begin{array}{l}\text { Emerging markets } \\
\text { dummy }\end{array}$ & $\begin{array}{l}0.0256 \\
(1.40)\end{array}$ & $\begin{array}{l}0.0159 \\
(0.89)\end{array}$ & $\begin{array}{l}0.0267 \\
(1.46)\end{array}$ \\
\hline SSA dummy & $\begin{array}{l}0.0752^{* * * *} \\
(3.21)\end{array}$ & $\begin{array}{l}0.0694 * * * \\
(3.10)\end{array}$ & $\begin{array}{l}0.0739 * * * \\
(3.18)\end{array}$ \\
\hline $\begin{array}{l}\text { Dummy 2006-12* } \\
\text { Advanced }\end{array}$ & $\begin{array}{c}0.0684 \\
(0.23)\end{array}$ & $\begin{array}{l}0.0021 \\
(0.08)\end{array}$ & $\begin{array}{l}0.0022 \\
(0.07)\end{array}$ \\
\hline $\begin{array}{c}\text { Dummy } 2006-12 * \\
\text { EM }\end{array}$ & $\begin{array}{l}-0.0193 \\
(-0.70)\end{array}$ & $\begin{array}{c}-0.0089 \\
(-0.34)\end{array}$ & $\begin{array}{c}-0.0206 \\
(-0.74)\end{array}$ \\
\hline $\begin{array}{c}\text { Dummy } 2006-12 * \\
\text { SSA }\end{array}$ & $\begin{array}{c}-0.0977 * * * \\
(-2.93)\end{array}$ & $\begin{array}{c}-0.0889 * * * \\
(-2.86)\end{array}$ & $\begin{array}{c}-0.0967 * * * \\
(-2.92)\end{array}$ \\
\hline Currency crisis $(\mathrm{t}-1)$ & $\begin{array}{c}0.0370 \\
(1.26)\end{array}$ & & \\
\hline $\begin{array}{l}\text { LV Currency crisis } \\
(\mathrm{t}-1)\end{array}$ & & $\begin{array}{c}-0.0147 \\
(-0.49)\end{array}$ & \\
\hline $\begin{array}{c}\text { Currency crisis }(\mathrm{t}-1) \\
10 \% \text { threshold }\end{array}$ & & & $\begin{array}{l}0.0525 * * \\
(2.05)\end{array}$ \\
\hline Banking crisis (t-1) & $\begin{array}{c}0.187 * * * \\
(3.82)\end{array}$ & $\begin{array}{c}0.212 * * * \\
(4.62)\end{array}$ & $\begin{array}{c}0.185 * * * \\
(3.80)\end{array}$ \\
\hline Debt crisis $(\mathrm{t}-1)$ & $\begin{array}{c}0.0424 \\
(0.65)\end{array}$ & $\begin{array}{l}0.0106 \\
(0.17)\end{array}$ & $\begin{array}{l}0.0372 \\
(0.57)\end{array}$ \\
\hline Inflation1 & $\begin{array}{c}0.00124 \\
(0.99)\end{array}$ & $\begin{array}{c}0.00136 \\
(1.20)\end{array}$ & $\begin{array}{c}0.00090 \\
(0.76)\end{array}$ \\
\hline $\begin{array}{c}\text { Inflation2 divided by } \\
10^{6}\end{array}$ & $\begin{array}{c}1.42 \\
(0.28)\end{array}$ & $\begin{array}{c}6.32 \\
(1.08)\end{array}$ & $\begin{array}{c}1.04 \\
(0.19)\end{array}$ \\
\hline Current Acc. /GDP & $\begin{array}{l}0.0765 \\
(0.91)\end{array}$ & $\begin{array}{l}0.0572 \\
(0.71)\end{array}$ & $\begin{array}{c}0.0779 \\
(0.92) \\
\end{array}$ \\
\hline DlnTOT & $\begin{array}{l}0.0023 \\
(0.04)\end{array}$ & $\begin{array}{l}0.0181 \\
(0.34)\end{array}$ & $\begin{array}{l}0.0016 \\
(0.92)\end{array}$ \\
\hline Year dummies? & Yes & Yes & Yes \\
\hline Sample size & 2924 & 3214 & 2924 \\
\hline R-squared & 0.1206 & 0.1320 & 0.1223 \\
\hline
\end{tabular}

Notes. See notes to Table 4. The sample is 1980 to 2012. TOT $=$ terms of trade. 


\section{Devaluations protect intermediate regimes from growth collapses}

So far it is just a theoretical presumption that growth collapses are less frequent under more flexible exchange rate regimes because of the scope for real depreciation. It is also possible to achieve real depreciation by devaluation in an adjustable peg regime (for example governments in the 1930 s were accused of using competitive devaluations to offset the impact of the Great Depression). Here we use data from Bleaney and Tian (2017) on the occurrence of parity changes (which are almost invariably devaluations) under pegged regimes to test whether devaluations reduce the probability of a growth collapse. We separate pegs (either to a single currency or to a basket of currencies) within the intermediate-regime category into those which have and those which have not experience a parity change in the previous year.

The results are shown in Table 6 . In Table 6 all the regime variables are one only if there is no crisis, so the omitted category is an independent float with no crisis. Intermediate regimes are divided into other pegs with no parity change, other pegs with a parity change and managed floats. Column (1) shows the results for the whole sample. Other pegs with no parity change have a coefficient of 0.0417 , with a t-statistic of 3.14 , but with a parity change the coefficient drops to an insignificant 0.0230 , indicating that parity changes reduce the probability of a growth collapse.

Because Table 3 shows that the regime effects tend to be weak in developing countries, in Column (2) of Table 6 we confine the sample to advanced countries and emerging markets. The estimated regime effects are quite a bit stronger than in Column (1): $+8.3 \%$ for hard pegs and $+7.7 \%$ for other pegs with no parity change. Other pegs with parity changes have a coefficient of only 0.0043 , or $0.4 \%$. Finally, in Column (3), we omit observations with growth collapses within the previous four years. The estimated hard-peg effect increases to $10.3 \%$, but the estimated effect of other pegs with no parity change falls to $+5.0 \%$, and $1.7 \%$ 
if there is a parity change. These results suggest that devaluations reduce the frequency of parity changes in pegged regimes. 
Table 6. Separating out pegs with parity changes

\begin{tabular}{|c|c|c|c|}
\hline & \multicolumn{3}{|c|}{$\begin{array}{c}\text { Probability of growth collapse } \\
\text { (GDP growth } 5 \% \text { or more below average of previous three } \\
\text { years) }\end{array}$} \\
\hline & (1) & (2) & (3) \\
\hline & Whole sample & $\begin{array}{l}\text { Advanced } \\
\text { countries \& } \\
\text { emerging } \\
\text { markets only }\end{array}$ & $\begin{array}{l}\text { Advanced \& } \\
\text { emerging only, no } \\
\text { growth collapse in } \\
\text { previous } 4 \text { years }\end{array}$ \\
\hline $\begin{array}{l}\text { Hard peg dummy, no } \\
\text { crisis (t-1) }\end{array}$ & $\begin{array}{c}0.0563 * * \\
(2.31)\end{array}$ & $\begin{array}{c}0.0831 * * * \\
(3.65)\end{array}$ & $\begin{array}{c}0.1032 * * * \\
(4.61)\end{array}$ \\
\hline $\begin{array}{l}\text { Other peg, no crisis, } \\
\text { no parity change (t-1) }\end{array}$ & $\begin{array}{l}0.0417 * * * \\
(3.14)\end{array}$ & $\begin{array}{c}0.0771 * * * \\
(3.57)\end{array}$ & $\begin{array}{l}0.0501 * * \\
(2.03)\end{array}$ \\
\hline $\begin{array}{l}\text { Other peg, no crisis, } \\
\text { parity change (t-1) }\end{array}$ & $\begin{array}{l}0.0230 \\
(1.04)\end{array}$ & $\begin{array}{c}0.0043 \\
(0.68)\end{array}$ & $\begin{array}{c}0.0171 \\
(0.47) \\
\end{array}$ \\
\hline $\begin{array}{l}\text { Managed float, no } \\
\text { crisis (t-1) }\end{array}$ & $\begin{array}{l}0.0053 \\
(0.32)\end{array}$ & $\begin{array}{c}0.0320^{*} \\
(1.92)\end{array}$ & $\begin{array}{l}0.0165 \\
(0.79)\end{array}$ \\
\hline $\begin{array}{l}\text { Advanced country } \\
\text { dummy }\end{array}$ & $\begin{array}{c}0.0090 \\
(0.50)\end{array}$ & $\begin{array}{l}0.0203 \\
(1.09)\end{array}$ & $\begin{array}{l}0.0281 \\
(1.17)\end{array}$ \\
\hline $\begin{array}{l}\text { Emerging markets } \\
\text { dummy }\end{array}$ & $\begin{array}{l}0.0256 \\
(1.44)\end{array}$ & & \\
\hline SSA dummy & $\begin{array}{c}0.0773 * * * \\
(3.35)\end{array}$ & & \\
\hline $\begin{array}{c}\text { Dummy 2006-12* } \\
\text { Advanced }\end{array}$ & $\begin{array}{c}0.0032 \\
(0.11) \\
\end{array}$ & $\begin{array}{c}0.0110 \\
(0.36)\end{array}$ & $\begin{array}{c}0.0008 \\
(0.02)\end{array}$ \\
\hline $\begin{array}{c}\text { Dummy 2006-12* } \\
\text { EM }\end{array}$ & $\begin{array}{l}-0.0162 \\
(-0.59)\end{array}$ & & \\
\hline $\begin{array}{c}\text { Dummy } 2006-12 * \\
\text { SSA }\end{array}$ & $\begin{array}{c}-0.0963 * * * \\
(-2.90) \\
\end{array}$ & & \\
\hline Crisis (t-1) & $\begin{array}{c}0.1000^{* * *} \\
(3.67)\end{array}$ & $\begin{array}{l}0.1497 * * * \\
(3.23)\end{array}$ & $\begin{array}{l}0.1097 \\
(1.38)\end{array}$ \\
\hline Inflation1 & $\begin{array}{c}0.00103 \\
(0.81)\end{array}$ & $\begin{array}{c}0.00506 * * \\
(2.36)\end{array}$ & $\begin{array}{c}0.00445^{*} \\
(1.86)\end{array}$ \\
\hline $\begin{array}{l}\text { Inflation2 divided by } \\
10^{6}\end{array}$ & $\begin{array}{l}-2.46 \\
(-0.54)\end{array}$ & $\begin{array}{l}26.3 * * \\
(2.40)\end{array}$ & $\begin{array}{c}133.5 * * * \\
(6.11)\end{array}$ \\
\hline Current Acc. /GDP & $\begin{array}{c}0.0898 \\
(1.07) \\
\end{array}$ & $\begin{array}{l}0.1325 \\
(1.04)\end{array}$ & $\begin{array}{l}0.0891 \\
(0.57)\end{array}$ \\
\hline Dln TOT & $\begin{array}{l}-0.0034 \\
(-0.06) \\
\end{array}$ & $\begin{array}{l}0.0291 \\
(0.38)\end{array}$ & $\begin{array}{l}0.1057 \\
(0.84)\end{array}$ \\
\hline Year dummies & Yes & Yes & Yes \\
\hline Sample size & 2922 & 1267 & 804 \\
\hline R-squared & 0.1148 & 0.2680 & 0.2750 \\
\hline
\end{tabular}

Notes. See notes to Table 4. The sample is 1980 to 2012. Data from Bleaney and Tian (2017) are used to separate intermediate regimes with and without parity changes. 


\section{Alternative definition of growth collapse}

Some authors include a condition of negative growth in their definition of a growth collapse. This restriction might make a significant difference to the results. Accordingly, in Table 7, we separate the cases of growth collapses where growth stays positive from the more frequent cases where it turns negative. Columns (1) and (2) show the results for a growth collapse with a positive and a negative growth rate respectively. Comparing Columns (1) and (2), it can be seen that the regime effects are somewhat different. For positive growth, the estimated intermediate regime effect of $+1.9 \%$ is significant at the five percent level, but the coefficient of the hard peg dummy is barely above one percent and not at all significant. For negative growth, the hard peg coefficient is $+7.0 \%$ and is significant at $1 \%$, whereas the intermediate regime coefficient is $+2.3 \%$ and only significant at $10 \%$. These results suggest that growth collapses under hard pegs almost always culminate in negative growth, whereas growth collapses under intermediate regimes only sometimes do so. It is not clear whether that is an economically significant difference, or whether it is just a random effect of the particular countries that happen to be involved in each case (for example it is not possible to have a growth collapse where growth remains positive if the growth rate only rarely exceeds $5 \%$ p.a.). Of course it has to be borne in mind that in these two regressions the dependent variable is zero not only when there is no growth collapse but also when there is a growth collapse of the other type, and this tends to make the regime coefficients a bit less positive relative to Column (1) of Table 4.

Another possible approach is to vary the definition of a growth collapse to allow for different intrinsic output volatility of different countries. We do this in Column (3) of Table 7. Defining the difference between the growth rate and its average over the previous three years as the "growth gap", we select a lower threshold than $-5 \%$ for the growth gap for country groups where the standard deviation of the growth gap is greater than $5 \%$. 
Specifically, we replace $-5 \%$ by minus one times the standard deviation in these cases. This moves the threshold to $-5.31 \%$ for emerging markets, $-8.75 \%$ for sub-Saharan Africa and $7.58 \%$ for other developing countries. Column (3) of Table 7 shows the results for this alternative measure of growth collapse. The much greater stringency of the criterion for identifying a growth collapse in developing countries changes the regional dummy coefficients quite a bit compared with Column (1) of Table (4). It also cuts the regime coefficients in size by about $40 \%$, so the estimated hard-peg effect is $+4.7 \%$, significant at the $5 \%$ level, compared with $+8.0 \%$ in Table 4 , and an intermediate-regime coefficient of $+2.6 \%$, significant at the $10 \%$ level, compared with $+4.3 \%$ in Table 4 .

In Table 8 we consider whether the regime effect varies systematically with country characteristics. To do so in a neat fashion, we collapse the two regime dummies into one, making use of the fact that the hard-peg coefficient is often about twice as large as the coefficient of intermediate regime dummy. We create a new variable called "fix", which measures how inflexible an exchange rate regime is; "fix" takes the value zero for floats, one for intermediate regimes and two for hard pegs. In Column (1) of Table 8, we just reproduce the regression from Column (1) of Table 4, but with the two regime dummies replaced by "fix". The coefficient of "fix" is 0.0398 , implying a $4.0 \%$ effect for intermediate regimes and an $8.0 \%$ effect for hard pegs, and is significant at the $1 \%$ level. 
Table 7. Different measures of growth collapse

\begin{tabular}{|c|c|c|c|}
\hline & (1) & (2) & (3) \\
\hline & $\begin{array}{c}\text { Growth collapse } \\
\text { with GDP growth } \geqslant \\
0\end{array}$ & $\begin{array}{c}\text { Growth collapse } \\
\text { with GDP growth }< \\
0\end{array}$ & $\begin{array}{l}\text { Adjusted measure of } \\
\text { growth collapse }\end{array}$ \\
\hline $\begin{array}{l}\text { Hard peg dummy (t- } \\
1)\end{array}$ & $\begin{array}{l}0.0105 \\
(0.67)\end{array}$ & $\begin{array}{c}0.0696 * * * \\
(3.67)\end{array}$ & $\begin{array}{l}0.0473 * * \\
(2.23)\end{array}$ \\
\hline $\begin{array}{l}\text { Intermediate regime } \\
(\mathrm{t}-1)\end{array}$ & $\begin{array}{c}0.0194 * * \\
(2.21)\end{array}$ & $\begin{array}{c}0.0232^{*} \\
(1.69)\end{array}$ & $\begin{array}{c}0.0255^{*} \\
(1.83)\end{array}$ \\
\hline $\begin{array}{l}\text { Advanced country } \\
\text { dummy }\end{array}$ & $\begin{array}{c}0.0112 \\
(1.11)\end{array}$ & $\begin{array}{c}0.0014 \\
(0.09)\end{array}$ & $\begin{array}{c}0.0283^{*} \\
(1.66)\end{array}$ \\
\hline $\begin{array}{l}\text { Emerging markets } \\
\text { dummy }\end{array}$ & $\begin{array}{c}0.0120^{*} \\
(1.72)\end{array}$ & $\begin{array}{c}0.0156 \\
(1.02)\end{array}$ & $\begin{array}{c}0.0281^{* *} \\
(2.23)\end{array}$ \\
\hline SSA dummy & $\begin{array}{l}0.0424 * * * \\
(3.69)\end{array}$ & $\begin{array}{c}0.0329 * \\
(1.70)\end{array}$ & $\begin{array}{l}0.0290 * * \\
(2.04)\end{array}$ \\
\hline $\begin{array}{c}\text { Dummy 2006-12* } \\
\text { Advanced }\end{array}$ & $\begin{array}{c}-0.0322^{*} \\
(-1.74)\end{array}$ & $\begin{array}{c}0.0429 \\
(1.63)\end{array}$ & $\begin{array}{l}0.0339 \\
(1.17)\end{array}$ \\
\hline $\begin{array}{l}\text { Dummy } 2006-12 * \\
\text { EM }\end{array}$ & $\begin{array}{l}-0.0139 \\
(-0.69)\end{array}$ & $\begin{array}{l}-0.0077 \\
(-0.34)\end{array}$ & $\begin{array}{c}0.0050 \\
(0.21)\end{array}$ \\
\hline $\begin{array}{c}\text { Dummy 2006-12* } \\
\text { SSA }\end{array}$ & $\begin{array}{c}-0.0457^{*} \\
(-1.66)\end{array}$ & $\begin{array}{l}-0.527^{*} \\
(-1.94)\end{array}$ & $\begin{array}{c}-0.0488^{*} \\
(-1.89)\end{array}$ \\
\hline Crisis $(\mathrm{t}-1)$ & $\begin{array}{l}0.0055 \\
(0.45)\end{array}$ & $\begin{array}{c}0.0761 * * * \\
(3.10)\end{array}$ & $\begin{array}{l}0.0809 * * * \\
(3.71)\end{array}$ \\
\hline Inflation 1 & $\begin{array}{c}0.00055 \\
(1.35)\end{array}$ & $\begin{array}{c}0.00054 \\
(0.45)\end{array}$ & $\begin{array}{c}0.00052 \\
(0.51)\end{array}$ \\
\hline $\begin{array}{l}\text { Inflation2 divided by } \\
10^{6}\end{array}$ & $\begin{array}{l}-2.30^{*} \\
(-1.92)\end{array}$ & $\begin{array}{c}0.78 \\
(0.17)\end{array}$ & $\begin{array}{l}-6.50^{*} \\
(-1.86)\end{array}$ \\
\hline Current Acc. /GDP & $\begin{array}{l}0.0391 \\
(0.49)\end{array}$ & $\begin{array}{l}0.0485 \\
(0.83)\end{array}$ & $\begin{array}{c}0.0118 \\
(0.17)\end{array}$ \\
\hline Dln TOT & $\begin{array}{l}0.0352 \\
(0.80)\end{array}$ & $\begin{array}{l}-0.0389 \\
(-0.84)\end{array}$ & $\begin{array}{l}-0.0136 \\
(-0.31)\end{array}$ \\
\hline Year dummies & Yes & Yes & Yes \\
\hline Sample & 2924 & 2924 & 2924 \\
\hline R-squared & 0.0357 & 0.1109 & 0.1192 \\
\hline
\end{tabular}

Notes. See notes to Table 4. Sample period: 1980-2012. Adjusted measure of growth collapse uses the following criterion: a fall in the GDP growth rate relative to the previous three years of $5.00 \%$ (advanced countries), 5.31\% (emerging markets), $8.75 \%$ (sub-Saharan Africa) and $7.58 \%$ (other developing countries). 
Having established that using "fix" is a reasonable simplification of the model, in the remainder of Table 8 we add some interactions of "fix" with other variables. We have already seen from Table 3 that it seems to be a phenomenon that is largely confined to advance countries and emerging markets. Thus it seems natural to consider whether the regime effect becomes stronger as income levels rise. Accordingly, in Column (2) of Table 8, we add an interaction term between "fix" and the logarithm of per capita GDP in constant US dollars. Another natural hypothesis is that the regime effect increases with openness to international trade, because the more open an economy is, the larger the share of exports in GDP, and therefore we expect a greater responsiveness of output to exchange rate movements. So in Column (3) of Table 3 we allow the regime effect to vary with the ratio of the sum of exports and imports to GDP. In Column (4) we allow for the two effects to operate simultaneously.

The results are as follows. In Column (2) the interaction with per capita GDP is positive and significant at the $1 \%$ level. The coefficient indicates that a doubling of per capita GDP (an addition of 0.693 in natural logarithms) is estimated to raise the probability of a growth collapse by $1.43 \%(0.693 \times 0.0207 \times 100)$. Since the per capita GDP variable is a deviation from its sample mean, the coefficient of "fix (t-1)" of 0.042 indicates a $4.2 \%$ probability of a growth collapse at mean levels of per capita GDP, when the deviation is zero. In Column (3) the interaction with trade openness is investigated. The coefficient of the interaction variable is positive, as expected, but nowhere near statistical significance, with a t-statistic of 1.09 . When the two interaction terms are included together in Column (4), however, the trade openness variable's coefficient shrinks by more than half, with a t-statistic of only 0.37 . Thus the effect of exchange rate inflexibility on the probability of a growth collapse seems to increase systematically with per capita GDP but not with trade openness. 
Table 8. Interactions between the regime effect and other variables

\begin{tabular}{|c|c|c|c|c|}
\hline & (GDP grow & $\begin{array}{r}\text { Grov } \\
b \text { or more be }\end{array}$ & $\begin{array}{l}\text { lapse } \\
\text { erage of pre }\end{array}$ & hree years) \\
\hline & $(1)$ & (2) & (3) & (4) \\
\hline Fix $(\mathrm{t}-1)$ & $\begin{array}{c}0.0398 * * * \\
(3.03)\end{array}$ & $\begin{array}{c}0.0418 * * * \\
(3.18)\end{array}$ & $\begin{array}{c}0.0349 * * \\
(2.55) \\
\end{array}$ & $\begin{array}{c}0.0414 * * * \\
(2.97)\end{array}$ \\
\hline $\begin{array}{c}\text { Fix (t-1)* } \\
\ln (\text { GDP p.c.) }\end{array}$ & & $\begin{array}{c}0.0207 * * \\
(2.42)\end{array}$ & & $\begin{array}{c}0.0185 * * \\
(2.44)\end{array}$ \\
\hline $\begin{array}{l}\text { Fix }(\mathrm{t}-1) * \\
\text { trade/GDP }\end{array}$ & & & $\begin{array}{l}0.0290 \\
(1.04)\end{array}$ & $\begin{array}{l}0.0104 \\
(0.37)\end{array}$ \\
\hline $\ln$ (GDP p.c.) & & $\begin{array}{c}0.0074 \\
(0.71)\end{array}$ & & $\begin{array}{l}0.0086 \\
(0.82)\end{array}$ \\
\hline Trade/GDP & & & $\begin{array}{l}-0.0077 \\
(-0.25)\end{array}$ & $\begin{array}{l}-0.0081 \\
(-0.25)\end{array}$ \\
\hline $\begin{array}{c}\text { Advanced } \\
\text { country dummy }\end{array}$ & $\begin{array}{l}0.0119 \\
(0.70)\end{array}$ & $\begin{array}{l}-0.0365 \\
(-1.31)\end{array}$ & $\begin{array}{c}-0.0059 \\
(-0.37)\end{array}$ & $\begin{array}{l}-0.0401 \\
(-1.42)\end{array}$ \\
\hline $\begin{array}{c}\text { Emerging } \\
\text { markets dummy }\end{array}$ & $\begin{array}{l}0.0277 \\
(1.54)\end{array}$ & $\begin{array}{c}0.0199 \\
(1.15)\end{array}$ & $\begin{array}{c}0.0335^{*} \\
(1.82)\end{array}$ & $\begin{array}{l}0.0212 \\
(1.18)\end{array}$ \\
\hline SSA dummy & $\begin{array}{c}0.0746^{* * * *} \\
(3.35)\end{array}$ & $\begin{array}{c}0.1056^{* * * *} \\
(4.18)\end{array}$ & $\begin{array}{c}0.0799 * * * \\
(3.48)\end{array}$ & $\begin{array}{c}0.1049 * * * \\
(4.16)\end{array}$ \\
\hline $\begin{array}{l}\text { Dummy 2006- } \\
12 * \text { Advanced }\end{array}$ & $\begin{array}{c}0.0096 \\
(0.32) \\
\end{array}$ & $\begin{array}{c}0.0190 \\
(0.62) \\
\end{array}$ & $\begin{array}{c}0.0053 \\
(0.16) \\
\end{array}$ & $\begin{array}{l}0.0132 \\
(0.42) \\
\end{array}$ \\
\hline $\begin{array}{c}\text { Dummy 2006- } \\
12 * \text { EM }\end{array}$ & $\begin{array}{c}-0.0217 \\
(-0.78)\end{array}$ & $\begin{array}{c}-0.0243 \\
(-0.88)\end{array}$ & $\begin{array}{l}-0.0312 \\
(-1.09)\end{array}$ & $\begin{array}{l}-0.0306 \\
(-1.06)\end{array}$ \\
\hline $\begin{array}{c}\text { Dummy 2006- } \\
12 * \text { SSA }\end{array}$ & $\begin{array}{c}-0.0982 * * * \\
(-2.95) \\
\end{array}$ & $\begin{array}{c}-0.0949 * * * \\
(-2.86)\end{array}$ & $\begin{array}{c}-0.1051^{* * * *} \\
(-3.06)\end{array}$ & $\begin{array}{c}-0.1015 \text { *** } \\
(-2.95)\end{array}$ \\
\hline Crisis (t-1) & $\begin{array}{c}0.0812 * * * \\
(3.14)\end{array}$ & $\begin{array}{c}0.0773 * * * \\
(3.00)\end{array}$ & $\begin{array}{c}0.0808 * * * \\
(3.11)\end{array}$ & $\begin{array}{c}0.0762 * * * \\
(2.94) \\
\end{array}$ \\
\hline Inflation1 & $\begin{array}{c}0.00113 \\
(0.92) \\
\end{array}$ & $\begin{array}{c}0.00114 \\
(0.92) \\
\end{array}$ & $\begin{array}{c}0.00110 \\
(0.87) \\
\end{array}$ & $\begin{array}{c}0.00110 \\
(0.87)\end{array}$ \\
\hline $\begin{array}{c}\text { Inflation } 2 \\
\text { divided by } 10^{6}\end{array}$ & $\begin{array}{l}-1.49 \\
(-0.33) \\
\end{array}$ & $\begin{array}{l}-1.10 \\
(-0.25) \\
\end{array}$ & $\begin{array}{l}-0.988 \\
(-0.21) \\
\end{array}$ & $\begin{array}{l}-0.942 \\
(-0.21) \\
\end{array}$ \\
\hline $\begin{array}{l}\text { Current Acc. } \\
\text { /GDP }\end{array}$ & $\begin{array}{c}0.0880 \\
(1.06) \\
\end{array}$ & $\begin{array}{c}0.0124 \\
(0.14) \\
\end{array}$ & $\begin{array}{l}0.0097 \\
(1.24) \\
\end{array}$ & $\begin{array}{l}0.0185 \\
(0.22) \\
\end{array}$ \\
\hline Dln TOT & $\begin{array}{c}-0.0037 \\
(-0.07) \\
\end{array}$ & $\begin{array}{c}-0.0077 \\
(-0.15) \\
\end{array}$ & $\begin{array}{c}-0.0142 \\
(-0.29) \\
\end{array}$ & $\begin{array}{l}-0.0115 \\
(-0.23) \\
\end{array}$ \\
\hline Year dummies & Yes & Yes & Yes & Yes \\
\hline Sample size & 2924 & 2913 & 2879 & 2869 \\
\hline R-squared & 0.1148 & 0.1250 & 0.1222 & 0.1294 \\
\hline
\end{tabular}

Notes. See notes to Table 4. The sample is 1980 to 2012. Fix=2 for hard pegs, $=1$ for intermediate regimes and $=0$ for independent floats. The two variables $\ln$ (GDP p.c.) and trade/GDP are in the form of deviations from their sample means. 


\section{CONCLUSIONS}

Growth collapses have serious consequences, resulting in a weak recovery and a permanent loss of output. This makes avoiding them an important objective of macroeconomic policy. Traditional theory suggests that negative shocks are likely to have larger output effects under fixed than under flexible exchange rates, and previous empirical work on terms-of-trade shocks has offered some support to this hypothesis. Recent experience of contractionary devaluations in the presence of sizeable foreign debt has raised some questions about this, although it is not usually suggested that such episodes have been associated with any particular pre-crisis exchange rate regime.

The contribution of the present paper has been to examine susceptibility to growth collapses under different exchange rate regimes for a wide range of countries over a thirtyyear period. In contrast to the results reported by Ghosh et al. (2015) for middle-income countries, the clear conclusion is that susceptibility increases with the fixity of the exchange rate regime, being greatest for hard pegs and smallest for independent floats, as traditional theory predicts. We have subjected our results to a battery of robustness tests, and we have shown that pegs that have been devalued have a lower probability of a growth collapse than those which have not been devalued, which is a clear indication that it is the potential for real depreciation that makes more flexible exchange rate regimes less susceptible to growth collapses. The exchange rate regime effect is significantly stronger in richer countries but does not vary significantly with the ratio of trade to GDP, which in a cross-country sample is more of an indication of smallness than of trade policy. 


\section{ACKNOWLEDGEMENTS}

The authors wish to thank an anonymous referee for helpful comments on a previous version. Any errors that remain are of course the authors' responsibility.

\section{REFERENCES}

Bleaney, M.F., S.C. Saxena and L. Yin (2016), Exchange rate regimes and growth collapses, Discussion Paper no. 16/02, University of Nottingham Centre for Finance, Credit and Macroeconomics.

Bleaney, M.F. and M. Tian (2017), Measuring exchange rate flexibility by regression methods, Oxford Economic Papers 69(1), 301-319.

Bleaney, M.F., M. Tian and L. Yin (2017), De facto exchange rate regime classifications: an evaluation, Open Economies Review 28(2), 369-382.

Broda, C. (2004) Terms of trade and exchange rate regimes in developing countries, Journal of International Economics 63, 31-58.

Calderón, C. and J.R.Fuentes (2014) Have business cycles changed over the last two decades? An empirical investigation, Journal of Development Economics 109, 98-123

Cerra, V., U. Panizza and S.C. Saxena (2013) International Evidence on Recovery from Recessions, Contemporary Economic Policy, 31(2): 424-439.

Cerra, V. and S.C. Saxena (2005) Growth Dynamics: The Myth of Economic Recovery, IMF Working Paper WP/05/147.

Cerra, V. and S.C. Saxena (2008) Growth dynamics: the myth of economic recovery, American Economic Review 98(1), 439-457.

Cerra, V. and S.C. Saxena (2017) Booms, Crises, and Recoveries: A New Paradigm of the Business Cycle and Its Policy Implications, IMF Working Paper no. 17/250.

Céspedes, L.F., R. Chang and A. Velasco (2004), Balance sheets and exchange rate policy, American Economic Review 94(4), 1183-1193.

Cook, D. (2004), Monetary policy in emerging markets: can liability dollarization explain contractionary devaluations? Journal of Monetary Economics 51(6), 1155-1181.

Edwards, S. and E. Levy-Yeyati (2005), Flexible exchange rates as shock absorbers, European Economic Review 49, 2079-2105.

Friedman, M. (1953), Essays in Positive Economics, Chicago: Chicago UP. 
Ghosh, A.R., J.D. Ostry and M.S. Qreshi (2015), Exchange rate management and crisis susceptibility: a reassessment, IMF Economic Review 63(1), 238-276.

Hausmann, R., L. Pritchett and D. Rodrik (1999), Growth accelerations, Journal of Economic Growth 10(4), 303-329.

Hausmann, R., F. Rodriguez and R. Wagner (2006), Growth collapses, Working Paper no. 136, Harvard University Center for International Development.

Jerzmanowski, M. (2006), Empirics of hills, plateaus, mountains and plains: a Markovswitching approach to growth, Journal of Development Economics 81, 357-385.

Kar, S., L. Pritchett, S. Raihan and K. Sen (2013), Looking for a break: Identifying transitions in growth regimes, Journal of Macroeconomics 38, 151-166.

Kerekes, M. (2012), Growth miracles and failures in a Markov switching classification model of growth, Journal of Development Economics 98, 167-177.

Laeven, L. and F. Valencia (2013), Systemic Banking Crises Database, IMF Economic Review 61(2), 225-270.

Lane, P.R. and G.-M. Milesi-Ferretti (2011) The cross-country incidence of the global crisis, IMF Economic Review 59(1), 77-110.

Reinhart, C.M. and K. Rogoff (2004), The modern history of exchange rate arrangements: a re-interpretation, Quarterly Journal of Economics 119, 1-48.

Rodrik, D. (1999), Where did all the growth go? External shocks, social conflict, and growth collapses, Journal of Economic Growth 4(4), 385-412.

Towbin, P. and S. Weber (2013), Limits of floating exchange rates: the role of foreign currency debt and import structure, Journal of Development Economics 101, 179-194. 


\section{ONLINE APPENDIX}

Table A1 - Growth dynamics

Table A2 - Probit model

Table A3 - Table 4 Column 1 regression with alternative regime classifications

Table A4 - Table 4 with different terms-of-trade coefficient for commodity exporters

Table A5 - List of countries in the sample 
Table A1. Growth rates of GDP before and after growth collapses 1980-2012

\begin{tabular}{|c|c|c|c|c|}
\hline \multirow{2}{*}{$\begin{array}{l}\text { Dependent } \\
\text { variable: }\end{array}$} & \multicolumn{4}{|c|}{ Growth rate of real GDP $(\%)$} \\
\hline & $1980-2012$ & $1980-2012$ & 1980-2005 & $2006-12$ \\
\hline & $(1)$ & $(2)$ & $(3)$ & $(4)$ \\
\hline $\begin{array}{l}\text { Year T-1 } \\
\text { Dummy }\end{array}$ & $\begin{array}{c}2.21 * * * \\
(3.53)\end{array}$ & $\begin{array}{c}2.50 * * * \\
(3.75)\end{array}$ & $\begin{array}{c}2.89 * * * \\
(3.13)\end{array}$ & $\begin{array}{l}-0.85 * * \\
(-2.06)\end{array}$ \\
\hline Year T Dummy & $\begin{array}{c}-9.44 * * * \\
(-17.6)\end{array}$ & $\begin{array}{c}-9.03 * * * \\
(-16.5)\end{array}$ & $\begin{array}{c}-9.78 * * * \\
(-13.1)\end{array}$ & $\begin{array}{c}-10.09 * * * \\
(-18.0)\end{array}$ \\
\hline $\begin{array}{l}\text { Year } \mathrm{T}+1 \\
\text { Dummy }\end{array}$ & $\begin{array}{c}-1.42 * * * \\
(-3.74)\end{array}$ & $\begin{array}{c}-1.28 * * * \\
(-3.30)\end{array}$ & $\begin{array}{c}-1.42 * * * \\
(-2.74)\end{array}$ & $\begin{array}{c}-2.59 * * * \\
(-5.05)\end{array}$ \\
\hline $\begin{array}{l}\text { Year T+2 } \\
\text { Dummy }\end{array}$ & $\begin{array}{c}-1.12 * * * \\
(-3.43)\end{array}$ & $\begin{array}{c}-0.90 * * * \\
(-2.63)\end{array}$ & $\begin{array}{c}-1.18 * * * \\
(-2.64)\end{array}$ & $\begin{array}{c}-2.33 * * * \\
(-4.62)\end{array}$ \\
\hline $\begin{array}{l}\text { Year } \mathrm{T}+3 \\
\text { Dummy }\end{array}$ & $\begin{array}{c}-2.01 * * * \\
(-5.31)\end{array}$ & $\begin{array}{c}-1.95 * * * \\
(-5.12)\end{array}$ & $\begin{array}{c}-1.92 * * * \\
(-4.60)\end{array}$ & $\begin{array}{c}-3.56 * * * \\
(-3.15)\end{array}$ \\
\hline $\begin{array}{l}\text { Year T+4 } \\
\text { Dummy }\end{array}$ & $\begin{array}{l}-0.92 * \\
(-1.97)\end{array}$ & $\begin{array}{l}-0.90 * \\
(-1.85)\end{array}$ & $\begin{array}{l}-0.62 \\
(-1.36)\end{array}$ & $\begin{array}{c}-2.51 * * * \\
(-3.37)\end{array}$ \\
\hline $\begin{array}{c}\text { Country fixed } \\
\text { effects? }\end{array}$ & yes & yes & yes & yes \\
\hline $\begin{array}{l}\text { Year fixed } \\
\text { effects? }\end{array}$ & no & yes & no & no \\
\hline Sample size & 4024 & 4024 & 2944 & 1080 \\
\hline RMSE & 5.39 & 5.36 & 5.83 & 3.18 \\
\hline
\end{tabular}

Notes. Year T is the year of a growth collapse, defined as a growth rate at least five percentage points below the average of the previous three years. The figures in parentheses are heteroscedasticity-robust $z$-statistics. $*, * *, * * *$ : significantly different from zero at the 10 , 5 and $1 \%$ levels respectively. 
Table A2. A probit analysis of exchange rate regimes and growth collapses

\begin{tabular}{|c|c|c|c|c|}
\hline & (GDP grow & $\begin{array}{l}\text { Grov } \\
\text { or more be }\end{array}$ & $\begin{array}{l}\text { llapse } \\
\text { erage of pre }\end{array}$ & three years) \\
\hline & \multicolumn{2}{|c|}{$1983-2005$} & \multicolumn{2}{|c|}{$2006-12$} \\
\hline & (1) & (2) & (3) & (4) \\
\hline $\begin{array}{l}\text { Hard peg } \\
(\mathrm{t}-1)\end{array}$ & $\begin{array}{l}0.0855^{* * * *} \\
(2.81)\end{array}$ & & $\begin{array}{c}0.1962 * * * \\
(2.83)\end{array}$ & \\
\hline $\begin{array}{c}\text { No separate } \\
\text { legal tender (t- } \\
1)\end{array}$ & & $\begin{array}{c}0.0769^{* *} \\
(2.48)\end{array}$ & & $\begin{array}{c}0.2431^{* * *} \\
(2.95)\end{array}$ \\
\hline $\begin{array}{l}\text { Currency board } \\
(\mathrm{t}-1)\end{array}$ & & $\begin{array}{l}0.1415^{* *} \\
(2.10)\end{array}$ & & $\begin{array}{l}0.1330 \\
(1.43)\end{array}$ \\
\hline $\begin{array}{l}\text { Intermediate } \\
\text { regime }(\mathrm{t}-1)\end{array}$ & $\begin{array}{c}0.0342 * * \\
(2.24) \\
\end{array}$ & & $\begin{array}{c}0.1001^{* * * *} \\
(3.00)\end{array}$ & \\
\hline $\begin{array}{l}\text { Peg to single } \\
\text { currency } \\
(\mathrm{t}-1)\end{array}$ & & $\begin{array}{c}0.0500 * * \\
(2.02)\end{array}$ & & $\begin{array}{c}0.1517 * * \\
(2.31)\end{array}$ \\
\hline $\begin{array}{l}\text { Other peg/band } \\
(\mathrm{t}-1)\end{array}$ & & $\begin{array}{c}0.0211 * * \\
(2.46)\end{array}$ & & $\begin{array}{c}0.1727 * * \\
(2.18) \\
\end{array}$ \\
\hline $\begin{array}{l}\text { Managed float } \\
(\mathrm{t}-1)\end{array}$ & & $\begin{array}{c}0.0022 \\
(0.11)\end{array}$ & & $\begin{array}{l}0.1224 * * \\
(2.18)\end{array}$ \\
\hline $\begin{array}{c}\text { Advanced } \\
\text { country dummy }\end{array}$ & $\begin{array}{c}-0.0402 * * * \\
(-2.76)\end{array}$ & $\begin{array}{c}-0.0420 * * \\
(-2.14)\end{array}$ & $\begin{array}{c}0.0769 * \\
(1.76)\end{array}$ & $\begin{array}{c}0.0883^{*} \\
(1.94)\end{array}$ \\
\hline $\begin{array}{c}\text { Emerging } \\
\text { markets dummy }\end{array}$ & $\begin{array}{c}0.0214 \\
(1.40)\end{array}$ & $\begin{array}{c}0.0226 \\
(1.50) \\
\end{array}$ & $\begin{array}{c}-0.0064 \\
(-0.26) \\
\end{array}$ & $\begin{array}{c}0.0003 \\
(0.01)\end{array}$ \\
\hline SSA dummy & $\begin{array}{l}0.0522 * * * \\
(3.20)\end{array}$ & $\begin{array}{c}0.0570 * * * \\
(3.32)\end{array}$ & $\begin{array}{c}-0.0446^{*} \\
(-1.81)\end{array}$ & $\begin{array}{c}-0.0479^{*} \\
(-1.91)\end{array}$ \\
\hline Crisis $(t-1)$ & $\begin{array}{c}0.0519 * * * \\
(4.46)\end{array}$ & $\begin{array}{c}0.0508 * * * \\
(4.39)\end{array}$ & $\begin{array}{c}0.1564 * * * \\
(4.24)\end{array}$ & $\begin{array}{c}0.1505^{* * * *} \\
(4.08)\end{array}$ \\
\hline Sample size & 2969 & 2969 & 999 & 999 \\
\hline $\begin{array}{l}\text { Pseudo-R } \\
\text { squared }\end{array}$ & 0.0449 & 0.0504 & 0.0576 & 0.0606 \\
\hline
\end{tabular}

Notes. The estimation method is probit, with a binary dependent variable (growth collapse $=1$; no growth collapse $=0$ ), where a growth collapse is defined as a growth rate at least five percentage points below the average of the previous three years. Marginal effects at the means of the independent variables are shown (in the case of dummy variables, marginal effects report the estimated effect of a shift from 0 to 1 ). The omitted regime category is an independent float, and the omitted country category is developing countries outside subSaharan Africa. The figures in parentheses are heteroscedasticity-robust $z$-statistics. *, **,***: significantly different from zero at the 10,5 and $1 \%$ levels respectively. 
Table A3. Alternative exchange rate regime classifications

\begin{tabular}{|c|c|c|c|}
\hline & \multicolumn{3}{|c|}{$\begin{array}{c}\text { Growth collapse } \\
\text { (GDP growth } 5 \% \text { or more below average of previous three } \\
\text { years) }\end{array}$} \\
\hline & (1) & (2) & (3) \\
\hline & $\begin{array}{l}\text { Bleaney-Tian } \\
\text { (2017) }\end{array}$ & $\begin{array}{c}\text { Reinhart-Rogoff } \\
\text { (2004) }\end{array}$ & IMF de jure \\
\hline $\begin{array}{l}\text { Hard peg dummy (t- } \\
1 \text { ) }\end{array}$ & $\begin{array}{l}0.0636^{* *} \\
(2.24)\end{array}$ & $\begin{array}{c}0.0396 \\
(1.29)\end{array}$ & $\begin{array}{c}0.0628 * * * \\
(2.71)\end{array}$ \\
\hline $\begin{array}{l}\text { Intermediate regime } \\
(\mathrm{t}-1)\end{array}$ & $\begin{array}{c}0.0191 * \\
(1.68)\end{array}$ & $\begin{array}{c}0.0130 \\
(0.48)\end{array}$ & $\begin{array}{l}0.0266^{* *} \\
(2.14)\end{array}$ \\
\hline $\begin{array}{c}\text { Advanced country } \\
\text { dummy }\end{array}$ & $\begin{array}{l}0.0105 \\
(0.60)\end{array}$ & $\begin{array}{c}0.0066 \\
(0.38)\end{array}$ & $\begin{array}{l}0.0056 \\
(0.33)\end{array}$ \\
\hline $\begin{array}{l}\text { Emerging markets } \\
\text { dummy }\end{array}$ & $\begin{array}{c}0.0292 * \\
(1.63)\end{array}$ & $\begin{array}{l}0.0245 \\
(1.53)\end{array}$ & $\begin{array}{c}0.0286 \\
(1.58)\end{array}$ \\
\hline SSA dummy & $\begin{array}{c}0.0722 * * * \\
(3.14)\end{array}$ & $\begin{array}{c}0.0770 * * * \\
(3.66)\end{array}$ & $\begin{array}{l}0.0751 * * * \\
(3.27)\end{array}$ \\
\hline $\begin{array}{c}\text { Dummy 2006-12* } \\
\text { Advanced }\end{array}$ & $\begin{array}{l}0.0018 \\
(0.06)\end{array}$ & $\begin{array}{c}-0.0014 \\
(-0.04)\end{array}$ & $\begin{array}{c}0.0054 \\
(0.18)\end{array}$ \\
\hline $\begin{array}{c}\text { Dummy 2006-12* } \\
\text { EM }\end{array}$ & $\begin{array}{c}-0.0187 \\
(-0.68)\end{array}$ & $\begin{array}{l}-0.0131 \\
(-0.41)\end{array}$ & $\begin{array}{c}-0.0214 \\
(-0.77)\end{array}$ \\
\hline $\begin{array}{c}\text { Dummy 2006-12* } \\
\text { SSA }\end{array}$ & $\begin{array}{c}-0.0963 * * * \\
(-2.92)\end{array}$ & $\begin{array}{c}-0.0967 * * \\
(-2.56)\end{array}$ & $\begin{array}{c}-0.0966^{* * *} \\
(-2.89)\end{array}$ \\
\hline Crisis (t-1) & $\begin{array}{c}0.0787 * * * \\
(3.03)\end{array}$ & $\begin{array}{c}0.1307 * * * \\
(3.93)\end{array}$ & $\begin{array}{c}0.0820 * * * \\
(3.17)\end{array}$ \\
\hline Inflation1 (t-1) & $\begin{array}{c}0.00135 \\
(1.05)\end{array}$ & $\begin{array}{c}0.00070 \\
(0.41)\end{array}$ & $\begin{array}{c}0.00114 \\
(0.92)\end{array}$ \\
\hline $\begin{array}{l}\text { Inflation } 2(\mathrm{t}-1) \\
\text { divided by } 10^{6}\end{array}$ & $\begin{array}{l}-1.12 \\
(-0.25)\end{array}$ & $\begin{array}{c}68.0 \\
(0.57)\end{array}$ & $\begin{array}{l}-0.588 \\
(-0.13)\end{array}$ \\
\hline $\begin{array}{c}\text { Current Acc. /GDP } \\
(\mathrm{t}-1)\end{array}$ & $\begin{array}{c}0.0938 \\
(1.16)\end{array}$ & $\begin{array}{c}0.1274 \\
(1.49) \\
\end{array}$ & $\begin{array}{l}0.0858 \\
(1.04) \\
\end{array}$ \\
\hline Dln TOT & $\begin{array}{l}-0.0066 \\
(-0.12)\end{array}$ & $\begin{array}{c}0.0256 \\
(0.41)\end{array}$ & $\begin{array}{l}-0.0028 \\
(-0.05)\end{array}$ \\
\hline Year dummies & Yes & Yes & Yes \\
\hline Sample & 2910 & 2447 & 2924 \\
\hline R-squared & 0.1120 & 0.1307 & 0.1143 \\
\hline
\end{tabular}

Notes. See notes to Table 4. Sample period: 1980-2012. 
Table A4. Allowing for different terms-of-trade effects for commodity exporters

\begin{tabular}{|c|c|c|c|c|}
\hline & \multicolumn{3}{|c|}{$\begin{array}{c}\text { Growth collapse } \\
\text { (GDP growth } 5 \% \text { or more below average of previous } \\
\text { three years) }\end{array}$} & \multirow{2}{*}{$\begin{array}{c}\text { Omitting } \\
\text { observations } \\
\text { within four } \\
\text { years of a } \\
\text { growth collapse } \\
\text { (4) }\end{array}$} \\
\hline & 774 & (2) & (3) & \\
\hline $\begin{array}{l}\text { Hard peg } \\
(\mathrm{t}-1)\end{array}$ & $\begin{array}{l}0.0800 * * * \\
(3.14)\end{array}$ & $\begin{array}{c}0.0635 * * * \\
(3.16)\end{array}$ & $\begin{array}{c}0.0771 * * * \\
(3.94)\end{array}$ & $\begin{array}{c}0.0573 * * \\
(2.34)\end{array}$ \\
\hline $\begin{array}{l}\text { Intermediate } \\
\text { regime }(\mathrm{t}-1)\end{array}$ & $\begin{array}{c}0.0426 * * * \\
(2.63)\end{array}$ & $\begin{array}{c}0.0347 * * \\
(2.17)\end{array}$ & $\begin{array}{c}0.0329 * * \\
(2.09)\end{array}$ & $\begin{array}{c}0.0240 \\
(1.40)\end{array}$ \\
\hline $\begin{array}{c}\text { Advanced } \\
\text { country dummy }\end{array}$ & $\begin{array}{l}0.0212 \\
(1.13)\end{array}$ & $\begin{array}{l}0.0100 \\
(0.53)\end{array}$ & $\begin{array}{l}-0.0029 \\
(-0.15) \\
\end{array}$ & $\begin{array}{c}0.0434 * \\
(1.89)\end{array}$ \\
\hline $\begin{array}{c}\text { Emerging } \\
\text { markets dummy }\end{array}$ & $\begin{array}{c}0.0308^{*} \\
(1.72)\end{array}$ & $\begin{array}{c}0.0213 \\
(1.23)\end{array}$ & $\begin{array}{l}0.0125 \\
(0.47)\end{array}$ & $\begin{array}{c}0.0459 * * \\
(2.51)\end{array}$ \\
\hline SSA dummy & $\begin{array}{c}0.0806^{* * * *} \\
(3.52)\end{array}$ & $\begin{array}{c}0.0753^{* * * *} \\
(3.45)\end{array}$ & $\begin{array}{c}0.0611 * * * \\
(2.84)\end{array}$ & $\begin{array}{c}0.0615^{* * * *} \\
(2.74)\end{array}$ \\
\hline $\begin{array}{l}\text { Dummy 2006- } \\
12 * \text { Advanced }\end{array}$ & $\begin{array}{l}0.0090 \\
(0.29)\end{array}$ & $\begin{array}{l}0.0085 \\
(0.31)\end{array}$ & $\begin{array}{l}0.0212 \\
(0.82)\end{array}$ & $\begin{array}{l}-0.0084 \\
(-0.20)\end{array}$ \\
\hline $\begin{array}{c}\text { Dummy 2006- } \\
12 * \mathrm{EM}\end{array}$ & $\begin{array}{l}-0.227 \\
(-0.82)\end{array}$ & $\begin{array}{c}-0.0136 \\
(-0.52) \\
\end{array}$ & $\begin{array}{l}-0.0059 \\
(-0.24)\end{array}$ & $\begin{array}{c}-0.0274 \\
(-0.83)\end{array}$ \\
\hline $\begin{array}{c}\text { Dummy 2006- } \\
12 * \text { SSA }\end{array}$ & $\begin{array}{c}-0.1007 * * * \\
(-3.04)\end{array}$ & $\begin{array}{c}-0.0930 * * * \\
(-3.01)\end{array}$ & $\begin{array}{c}-0.0858 * * * \\
(-2.96) \\
\end{array}$ & $\begin{array}{c}-0.0947 * * * \\
(-2.70) \\
\end{array}$ \\
\hline Crisis (t-1) & $\begin{array}{l}0.0802 * * * \\
(3.10)\end{array}$ & & & $\begin{array}{l}0.0388 \\
(0.92)\end{array}$ \\
\hline LV Crisis (t-1) & & $\begin{array}{c}0.0824 * * * \\
(3.19)\end{array}$ & & \\
\hline Inflation1 & $\begin{array}{c}0.00089 \\
(0.70)\end{array}$ & $\begin{array}{c}0.00090 \\
(0.77)\end{array}$ & $\begin{array}{l}0.00163 \\
(1.46)\end{array}$ & $\begin{array}{c}-0.00018 \\
(-0.08)\end{array}$ \\
\hline $\begin{array}{c}\text { Inflation } 2 \\
\text { divided by } 10^{6}\end{array}$ & $\begin{array}{c}-1.43 \\
(-0.32) \\
\end{array}$ & $\begin{array}{c}6.40 \\
(1.27) \\
\end{array}$ & $\begin{array}{l}5.65 \\
(1.16) \\
\end{array}$ & $\begin{array}{c}1571 * * * \\
(8.20)\end{array}$ \\
\hline $\begin{array}{l}\text { Current Acc. } \\
\text { /GDP }\end{array}$ & $\begin{array}{l}0.0751 \\
(0.94)\end{array}$ & $\begin{array}{l}0.0473 \\
(0.62)\end{array}$ & $\begin{array}{l}0.0337 \\
(0.49)\end{array}$ & $\begin{array}{l}-0.0592 \\
(-0.75)\end{array}$ \\
\hline Dln TOT & $\begin{array}{c}0.0120 \\
(0.13)\end{array}$ & $\begin{array}{c}0.0205 \\
(0.22)\end{array}$ & $\begin{array}{c}0.0311 \\
(0.36)\end{array}$ & $\begin{array}{l}-0.0008 \\
(-0.01)\end{array}$ \\
\hline $\begin{array}{l}\text { Commodity } \\
\text { exporter (CE) }\end{array}$ & $\begin{array}{c}0.0189 \\
(1.06)\end{array}$ & $\begin{array}{c}0.0194 \\
(1.13)\end{array}$ & $\begin{array}{l}0.153 \\
(0.93) \\
\end{array}$ & $\begin{array}{c}0.0179 \\
(1.00)\end{array}$ \\
\hline $\mathrm{CE}^{*} \mathrm{~d} \ln \mathrm{TOT}$ & $\begin{array}{l}-0.0356 \\
(-0.32)\end{array}$ & $\begin{array}{l}-0.0141 \\
(-0.13)\end{array}$ & $\begin{array}{l}-0.0026 \\
(-0.02)\end{array}$ & $\begin{array}{l}0.1416 \\
(1.13)\end{array}$ \\
\hline Year dummies & Yes & Yes & Yes & Yes \\
\hline Sample size & 2924 & 3214 & 3430 & 1771 \\
\hline R-squared & 0.1155 & 0.1244 & 0.1211 & 0.1408 \\
\hline
\end{tabular}

Notes. This table reproduces Table 4 with the addition of a commodity exporter dummy and its interaction with the terms of trade. The dummy is equal to one if on average between 1962 and 2014 (a) commodities constituted at least 35 percent of total exports; and (b) net commodity exports accounted for at least 5 percent of gross trade. 
Appendix Table A5. The countries in in the sample

\begin{tabular}{|c|c|c|c|}
\hline $\begin{array}{c}\text { Advanced } \\
\text { economies(35) }\end{array}$ & $\begin{array}{c}\text { Emerging } \\
\text { markets(42) }\end{array}$ & $\begin{array}{c}\text { Sub-Saharan } \\
\text { Africa(42) }\end{array}$ & $\begin{array}{c}\text { Developing } \\
\text { economies (except } \\
\text { SSA, 57) }\end{array}$ \\
\hline $\begin{array}{l}\text { United States } \\
\text { United Kingdom } \\
\text { Austria } \\
\text { Belgium } \\
\text { Denmark } \\
\text { France } \\
\text { Germany } \\
\text { Italy } \\
\text { Luxembourg } \\
\text { Netherlands } \\
\text { Norway } \\
\text { Sweden } \\
\text { Switzerland } \\
\text { Canada } \\
\text { Japan } \\
\text { Finland } \\
\text { Greece } \\
\text { Iceland } \\
\text { Ireland } \\
\text { Malta } \\
\text { Portugal } \\
\text { Spain } \\
\text { Australia } \\
\text { New Zealand } \\
\text { Cyprus } \\
\text { Israel } \\
\text { China,P.R.:Hong } \\
\text { Kong } \\
\text { Korea, Republic of } \\
\text { Singapore } \\
\text { Czech Republic } \\
\text { Slovak Republic } \\
\text { Estonia } \\
\text { Latvia } \\
\text { Lithuania } \\
\text { Slovenia } \\
\text { Sola }\end{array}$ & 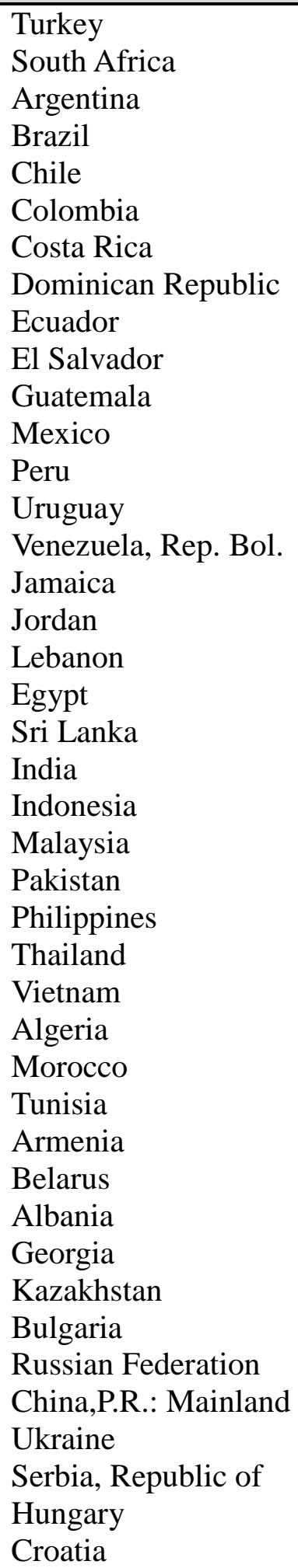 & $\begin{array}{l}\text { Angola } \\
\text { Botswana } \\
\text { Burundi } \\
\text { Cameroon } \\
\text { Cape Verde } \\
\text { Central African Rep. } \\
\text { Chad } \\
\text { Comoros } \\
\text { Congo, Republic of } \\
\text { Congo, Dem. Rep. of } \\
\text { Benin } \\
\text { Equatorial Guinea } \\
\text { Eritrea } \\
\text { Ethiopia } \\
\text { Gabon } \\
\text { Gambia, The } \\
\text { Ghana } \\
\text { Guinea-Bissau } \\
\text { Guinea } \\
\text { Côte d'Ivoire } \\
\text { Kenya } \\
\text { Lesotho } \\
\text { Liberia } \\
\text { Madagascar } \\
\text { Malawi } \\
\text { Mali } \\
\text { Mauritania } \\
\text { Mozambique } \\
\text { Niger } \\
\text { Nigeria } \\
\text { Zimbabwe } \\
\text { Rwanda } \\
\text { Sío Tomé \& Príncipe } \\
\text { Seychelles } \\
\text { Senegal } \\
\text { Sierra Leone } \\
\text { Namibia } \\
\text { Swaziland } \\
\text { Tanzania } \\
\text { Togo } \\
\text { Uganda } \\
\text { Burkina Faso }\end{array}$ & $\begin{array}{l}\text { Bolivia } \\
\text { Haiti } \\
\text { Honduras } \\
\text { Nicaragua } \\
\text { Panama } \\
\text { Paraguay } \\
\text { Antigua and Barbuda } \\
\text { Bahamas, The } \\
\text { Barbados } \\
\text { Dominica } \\
\text { Grenada } \\
\text { Guyana } \\
\text { Belize } \\
\text { St. Kitts and Nevis } \\
\text { St. Lucia } \\
\text { St. Vincent \& Grens. } \\
\text { Suriname } \\
\text { Trinidad and Tobago } \\
\text { Bahrain, Kingdom of } \\
\text { Iran, I.R. of } \\
\text { Iraq } \\
\text { Kuwait } \\
\text { Oman } \\
\text { Qatar } \\
\text { Saudi Arabia } \\
\text { Syrian Arab Republic } \\
\text { United Arab Emirates } \\
\text { Yemen, Republic of } \\
\text { Afghanistan, I.R. of } \\
\text { Bangladesh } \\
\text { Bhutan } \\
\text { Brunei Darussalam } \\
\text { Myanmar } \\
\text { Cambodia } \\
\text { Timor-Leste } \\
\text { Lao People's } \\
\text { Dem.Rep } \\
\text { Maldives } \\
\text { Nepal } \\
\text { Djibouti } \\
\text { Libya } \\
\text { Mauritius } \\
\text { Sala }\end{array}$ \\
\hline
\end{tabular}




\begin{tabular}{|l|l|l|}
\hline & Macedonia, FYR & Sudan \\
Bosnia \& & Zambia \\
Herzegovina & Poland & Solomon Islands \\
Romania & Fiji \\
& Kiribati \\
& Vanuatu \\
& Papua New Guinea \\
& Samoa \\
& Tonga \\
& Azerbaijan, Rep. of \\
& Kyrgyz Republic \\
& Moldova \\
& Tajikistan \\
& Turkmenistan \\
& Uzbekistan \\
& Montenegro \\
\end{tabular}

